\title{
Aberrant DNA methylation profile exacerbates inflammation and neurodegeneration in multiple sclerosis patients
}

\author{
Naiara Celarain ${ }^{*}$ and Jordi Tomas-Roig ${ }^{*}$ (I)
}

\begin{abstract}
Multiple sclerosis (MS) is an autoimmune and demyelinating disease of the central nervous system characterised by incoordination, sensory loss, weakness, changes in bladder capacity and bowel function, fatigue and cognitive impairment, creating a significant socioeconomic burden. The pathogenesis of MS involves both genetic susceptibility and exposure to distinct environmental risk factors. The gene $x$ environment interaction is regulated by epigenetic mechanisms. Epigenetics refers to a complex system that modifies gene expression without altering the DNA sequence. The most studied epigenetic mechanism is DNA methylation. This epigenetic mark participates in distinct MS pathophysiological processes, including blood-brain barrier breakdown, inflammatory response, demyelination, remyelination failure and neurodegeneration. In this study, we also accurately summarised a list of environmental factors involved in the MS pathogenesis and its clinical course. A literature search was conducted using MEDLINE through PubMED and Scopus. In conclusion, an exhaustive study of DNA methylation might contribute towards new pharmacological interventions in MS by use of epigenetic drugs.
\end{abstract}

Keywords: Multiple sclerosis, DNA methylation, Environmental risk factors, Inflammation, Neurodegeneration

\section{Background}

Multiple sclerosis (MS) is an autoimmune, inflammatory, demyelinating and neurodegenerative disease of the central nervous system (CNS) [1]. As a result of myelin sheath destruction, the electric impulse between neurons is inefficient, and thus the initial symptoms appear [2]. Although symptoms differ from each MS patient, the most common ones include incoordination, sensory loss, weakness, changes in bladder capacity and bowel function, fatigue, and cognitive impairment [3]. Therefore, MS has serious negative effects on the health-, social, and work-related issues of patients and their families, creating a significant socioeconomic burden [4]. The aetiology of MS is still unknown and requires a close interaction between genetic susceptibility and exposure to environmental agents. Synergistic effect of these risk

\footnotetext{
* Correspondence: ncelarain@idibgi.org; jtomas@idibgi.org

Girona Neuroimmunology and Multiple Sclerosis Unit (UNIEM), Dr. Josep Trueta University Hospital and Girona Biomedical Research Institute (IDIBGI), Girona, Spain
}

factors would be responsible for triggering autoimmunity in MS patients. For this reason, the underlying mechanisms involved in the MS pathogenesis can differ among patients. Common mechanisms are observed in the pathophysiology of disease and listed next. Autoreactive $\mathrm{CD} 4+\mathrm{T}$ cells are activated in the periphery [1] by antigen-presenting cells (APC), that present via the class II major histocompatibility complex (MHC) receptor an amino acid similar to myelin peptides synthesised in the CNS. This interaction activates the differentiation of the CD4+ T naïve cells into CD4+ T helper cells [5]. Upon activation, the Th1 subtype produces interferon gamma (IFN- $\gamma$ ) [6], a cytokine responsible for recruiting CD8+ $\mathrm{T}$ cells, $\mathrm{B}$ cells and monocytes in the periphery [7]. Then, these proinflammatory cells migrate to the bloodbrain barrier (BBB) throughout the bloodstream, where they can adhere to the BBB endothelium [8]. In a healthy brain, immune cells are circulating freely in the meninges orchestrating immune surveillance of the CNS [9]. In MS, the $\mathrm{BBB}$ displays an aberrant expression and 
organisation of the endothelial tight junctions [10] that favours massive lymphocyte trafficking into the brain [11]. Infiltrated CD4+ T cells in the CNS are reactivated upon interaction with the resident APCs [12]. Afterwards, the reactivated $\mathrm{CD} 4+\mathrm{T}$ cells release a variety of proinflammatory cytokines and chemokines [13], resulting in astrogliosis [14] and microgliosis [15]. This process is exacerbated when infiltrated cytotoxic CD8+ $\mathrm{T}$ cells attack oligodendrocytes, causing their destruction and neuronal death [16]. In parallel, plasma B cells produce antibodies against CNS self-antigens, contributing to myelin sheath damage [17]. Plasma B cells in coordination with monocytes increase the local inflammatory response by reactivating the autoreactive $\mathrm{CD} 4+\mathrm{T}$ cells [18] (Fig. 1). T cell-mediated axonal injury contributes to trophic/metabolic support deficiency from oligodendrocytes as well as a lack of energy by releasing soluble inflammatory molecules [19]. The pathophysiology of MS suggests a complex interaction between the genetic and environmental risk factors [20] regulated by epigenetic mechanisms. Epigenetics can provide a stable heritable base for understanding the underlying mechanisms involved in MS [21].

\section{Genetic, epigenetic and environmental factors}

The robust susceptibility loci that confer risk for MS are the human leukocyte antigen (HLA) system, which is located in the short arm of chromosome 6 [22]. However, only $27 \%$ of MS heritability can be explained by the genetic variants of the HLA system [23], which supports a prominent contribution of the environment to the MS pathogenesis. Indeed, Epstein Barr virus (EBV) infection, tobacco smoking, vitamin D deficiency, diet style and sun light exposure are critically involved in MS susceptibility [24, 25]. The individual genetic background in combination with the environmental risk factors increase the probability of developing MS. Epigenetic modifications do not alter the sequence of DNA, and they comprise distinct mechanisms such as DNA methylation (DNAme), histone modifications and micro-RNA [26]. Given the scope of this review, we focus our efforts on describing the contribution of DNAme in MS.

\section{DNA methylation}

DNAme is the most current epigenetic hallmark in human somatic cells [27]. The methylation of DNA occurs when a methyl group is transferred to the fifth carbon of a cytosine $(5 \mathrm{mC})$ through the action of DNA methyltransferases (DNMT). This process occurs mainly in CG dinucleotides, which are commonly found in the regulatory and promoter regions [28]. The addition of methyl groups in the promoter region contributes to gene silencing [28]. In mammals, DNMTs are mainly represented by DNMT1, DNMT3a and DNMT3b. DNMT1 acts during the cell cycle to maintain the DNAme pattern [29] and participates in the DNA repair system [30]. By contrast, DNMT3a and DNMT3b catalyse the de novo addition of a methyl group into a naked cytosine [31]. This fact occurs in cooperation with either the specific transcription factors or the binding transcription factors, which methylate all the CpG sites uncovered [32].

DNAme is a dynamic process that usually requires the removal of the methyl group (demethylation) to cope with environmental stimuli [33]. This process can be achieved in a passive or active manner. Passive DNA demethylation occurs when DNMT1 activity is misregulated and cannot maintain the integrity of the DNAme pattern during the DNA replication, leading to the incorporation of unmethylated cytosine into the genome [34]. Active DNA demethylation is achieved when a sequence of enzymatic reactions of oxidation and/or deamination modifies 5 -methylcytosine $(5 \mathrm{mC})$ to obtain a naked cytosine. In the oxidation pathway, $5 \mathrm{mC}$ is oxidised by the ten-eleven translocation (TET) enzymes to 5hydroxymethylcytosine $(5 \mathrm{hmC})$ [35], which can be further oxidised to 5-formylcytosine $(5 \mathrm{fC})$ and 5-carboxylcytosine $(5 \mathrm{caC})$ [36]. In the deamination pathway, AID or APOBEC deaminates $5 \mathrm{hmC}$ to 5 -hydroxymethyluracil $(5 \mathrm{hmU}$ ) or $5 \mathrm{mC}$ to thymine [37]. Eventually, all these modified bases $(5 \mathrm{hmU}$, Thymine, $5 \mathrm{fC}, 5 \mathrm{caC}$ ) can be recognised by thymine DNA glycosylase (TDG) [38] and converted to naked cytosine through the base excision repair pathway (Fig. 2).

\section{Contribution of DNA methylation in patients with MS}

Although the precise role of the DNAme in MS remains to be fully elucidated, several studies have reported differentially methylated regions in both the immune cells and brain tissue collected from MS patients (Table 1). Therefore, we summarise the current published research on DNAme as follows: BBB breakdown, inflammation, demyelination, remyelination failure and neurodegeneration.

\section{BBB breakdown}

Infiltration of the autoreactive proinflammatory cells across the $\mathrm{BBB}$ into the brain is one of the pathological features of MS [62]. The BBB is a selective semi-permeable endothelium that separates the CNS from the circulating blood. This barrier is composed of a monolayer of endothelial cells tightly bound mainly by cadherins [63] and intercellular adhesion molecule (ICAM) proteins [64]. Cadherins are calcium-dependent adhesion molecules importantly involved in cell-cell adhesion [63]. The disruption of cell-cell interaction mediated by cadherins leads to $\mathrm{BBB}$ permeability [63]. A hypermethylated pattern of E-cadherin (CDH1) may increase the BBB permeability in relapsing-remitting MS (RRMS) patients favouring lymphocyte infiltration into the brain, and lastly, disease progression $[47,56]$. The other adhesion 


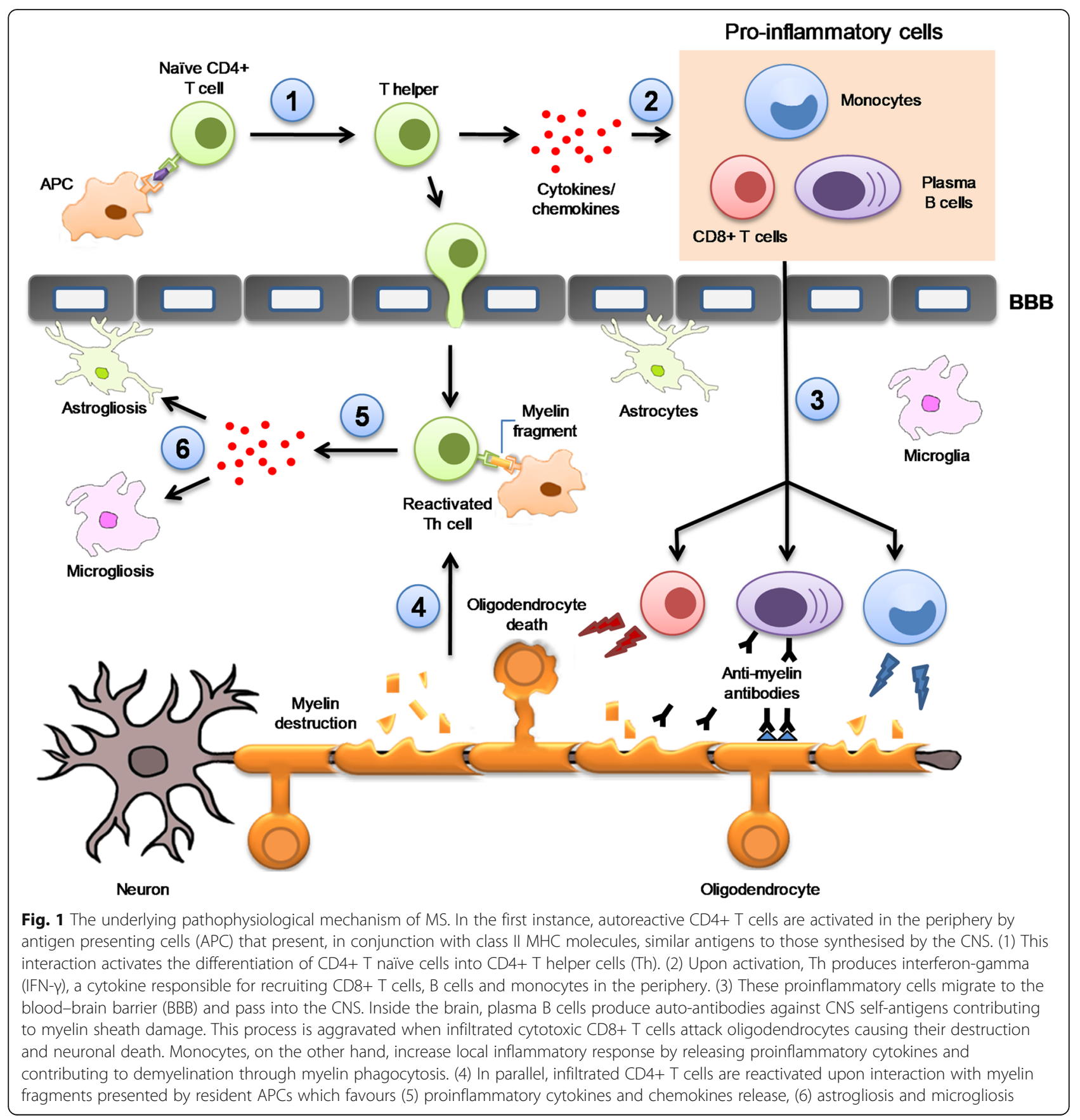

molecules expressing on the $\mathrm{BBB}$ endothelium are the ICAM family. In particular, ICAM-1 is essential for leukocyte crawling prior to diapedesis from the bloodstream to the CNS [65] and plays a remarkable role in $\mathrm{T}$ cell proliferation [66]. Liggett et al. (2010) reported a hypermethylation pattern for ICAM1 in cell-free plasma DNA derived from RRMS patients in response to clinical remission, indicating an impairment of the $\mathrm{T}$ cell extravasation into the brain as a consequence of immune response mitigation [56]. These findings are in accordance with the results reported in knockout mice for Icam 1 subjected to the experimental autoimmune/allergic encephalomyelitis (EAE) model [66].

\section{Inflammation}

The first inflammatory event in MS is conducted when APC through the class II MHC complex presents a specific antigen to naïve $\mathrm{CD} 4+\mathrm{T}$ cells, which favour $\mathrm{T}$ cell differentiation and the recruitment of proinflammatory cells into the CNS [5]. MHC, also known as human leukocyte antigen (HLA), is responsible for presenting non-self-antigens to the $\mathrm{T}$ cell receptors and natural 


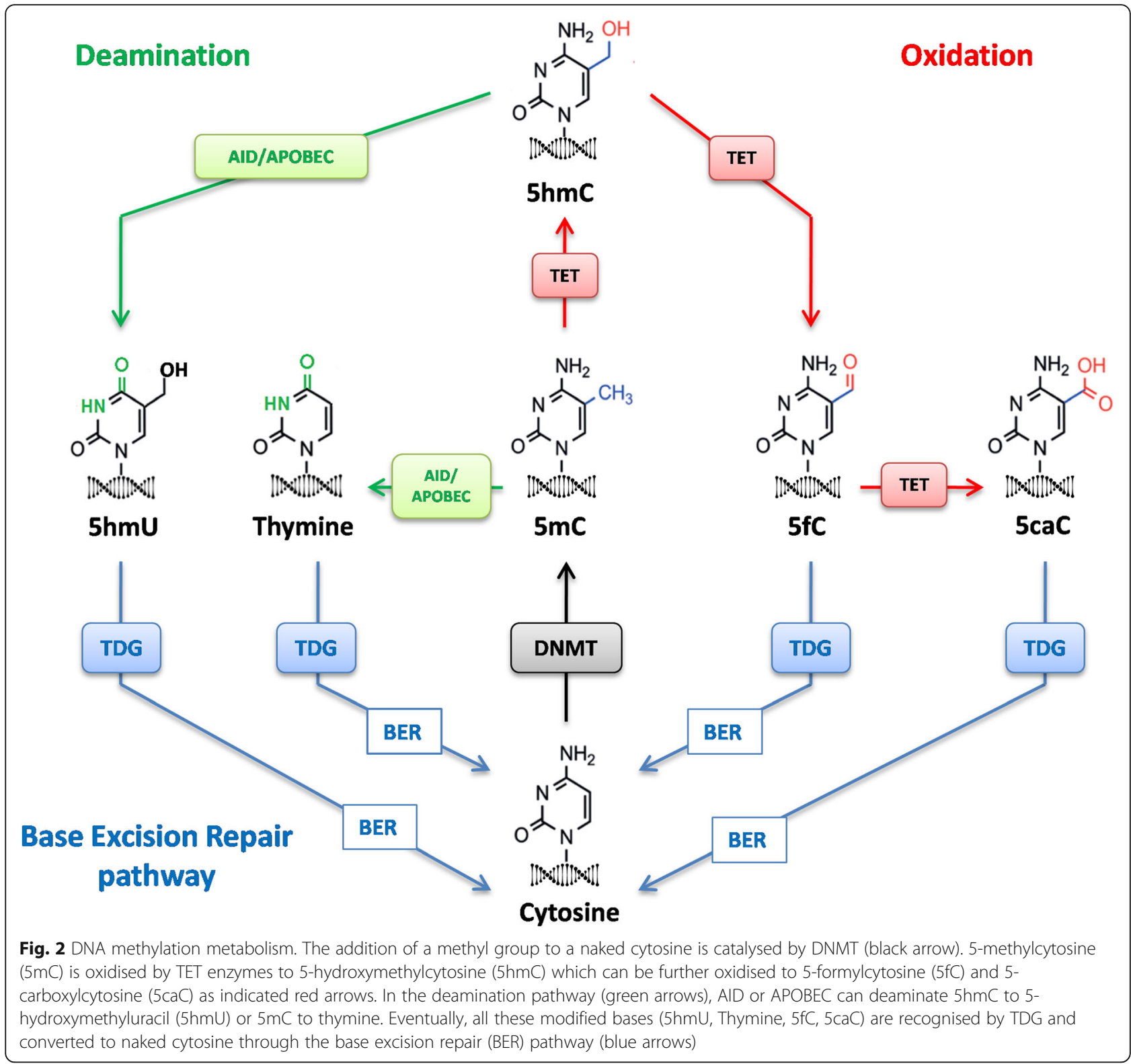

killer receptors (NKRs) [67] facilitating the inflammatory response. Leukocytes use the HLA complex to distinguish self-proteins from exogenous components [68]. In MS, certain HLA genes showed an aberrant methylation pattern contributing to MS aetiology [47]. For example, the hypomethylation of MHC class I polypeptide-related sequence $\mathrm{B}$ (MICB) has been reported in normal appearing white matter (NAWM) [47] and CD4+ T cells in MS patients [40]. In MS, a ligand codified by MICB activates the NK and CD8+ T cell destruction [69]. Similarly, the HLA-F variant is actively expressed in the inflammatory reaction [67] as a result of its promoter demethylation $[43,47]$. Aside from the HLA complex, changes in DNAme are found in other inflammatory pathways reported in MS. Specifically, global CG island hypermethylation of the Src homology region 2 domaincontaining phosphatase- 1 and the suppressor of cytokine signalling 1 might aggravate the course of MS through the overactivation of the immune-mediated response $[49,56,57]$. Adhesion molecules such as ICAM5 are markedly present in the cerebral and hippocampal neurons [70]. In MS, the extracellular domain of ICAM5 is cleaved and released into the cerebrospinal fluid (CSF) and blood, where it modulates the synthesis of proinflammatory cytokines (TNF- $\alpha$, IL-1 $\beta$ ), stimulates the expression of anti-inflammatory cytokine IL-10 and represses $T$ cell activation [71]. As a result of disease progression, primary progressive MS (PPMS) patients with non-recoverable demyelination and neurodegeneration showed higher methylation levels for ICAM5 than 
Table 1 DNA methylation changes in MS

\begin{tabular}{|c|c|c|c|c|}
\hline References & Comparison & $\begin{array}{l}\text { Sample } \\
\text { target }\end{array}$ & Method & Differentially methylated genes \\
\hline [39] & MS vs CTR & CD8+ T cells & Illumina 450K array & $\begin{array}{l}\text { ERG, FTL, DCAF4, NCAPH2, CDKN1C, ZNF462, CBX7, MIR492, HPS1, } \\
\text { SASH1, MYL3, KCNG1, DYDC2, MEGF10, SP5, LMO3, SLC12A7, MORN1, } \\
\text { IGF2BP1, PLCB3, ABCC4, CREG2, CDC42BPB, UGT1A10, TMEM125, } \\
\text { ARHGAP22, DACH1, OR8B12, TMEM8C, BAI1, EIF2S1, CRTAC1, DHX36, } \\
\text { C19orf41, DLGAP2, TNXB, PRDM8, HEATR2, WHSC2, CAMTA1, ALK, } \\
\text { KCNQ2, SCTR, RHEB, LOC202181, RRP9, KRT75, DGKE, PLD5, ZC3H14. }\end{array}$ \\
\hline
\end{tabular}

[40] RRMS vs CTR CD4+ T cells Illumina 450K array

[41] Myelinated vs demyelinated MS brains $\mathrm{CTR}$ smoker MS
PMBCS

Microarray dataset and RTPCR

Hippocampus Illumina 450K array

Illumina 450K array

Bisulphite Illumina Methylation 450k Beadchip

Direct

BS-sequencing

cfDNA (whole blood)

NAWM

BS-PCR sequencing assay

Bisulphite Illumina
MICA, MICB, HLA-DRB, MORN1, LCLAT1, PDCD1, MUC4, AHRR, ARSB, PCBD2, TGFBI, PCDHB13, PCDHB15, KIF25, CSGALNACT1, ADARB2, LDHAL6A, CORO1B, USP35, FUT4, ERC1, TCRA, PACS2, IL32, KCTD11, C17orf108, ARHGAP27, NPLOC4, SBNO2, GNG7, C21orf56, RIBC2.

MLLT4, PPIF, SCRT2, SNRNP40, ISLR2, MEF2A, PMEPA1, ABCA4, ADAMTS12, AHRR, BEST3, CASP7, CCL4L2, CPXM2, FBXW8, HLA-B, LOC145845, MEIS1, MGMT, MYO7A, NXN, PKP2, PQLC1, PSD3, SCN4B, SDK2, SMYD3, TGFBI, TMEM165, PON1, HDLBP, MKKS, TRIM26, TRPS1, KRTAP27-1, MGP, AJAP1, C1 orf106, C2orf62, DSE, EIF2C2, GATA5, HLA-B, IGSF9B, INSC, KIAA1026, KIF25, LOC100292680, NFASC, RASA3, SDK1, SHISA2, SOLH, SORBS2, TAGLN3, TBX5, TM9SF1, TOP1MT, ZSCAN1, AKNA, EBPL, FLJ42709, HERC6, OR52M1, SFRP1, C22orf43, LOC285830, NAPEPLD, NHLH2, PLCH1, SERPINA9, SLFN13, TMEM132B, TTLL3, WDR81.

DNMT3A, GADD45A, GADD45B, MBD4, APOBEC3D, APOBEC4, GADD45G, TET1, TDG, APOBEC3C, APOBEC2, MBD2, MBD3, APOBEC3A, DNMT3B, APOBEC1, TET2, TET3.

RRMS vs CTR: ASB2, ATP11A, CACNA2D3, CERS5, ESRRG, FRMD4A, GNAS, HOXC4-HOXC6, IFITM5, ILDR1, KCNK15, KLHL35, LEFTY2, PLEKHA2, RPH3AL, WRAP73, ZFYVE28.PPMS vs CTR: ATG16L2, CES1, CSGALNACT2, CYB5D1, LSMD1, FAM110A, GDF7, HKR1, HLA-F, HOXB13, IGSF9B, ILDR1, LDB2, MTPN, LUZP6, NTN1, OPCML, OR2L13, RBM46, TBX1, TCP10L, TMEM44, VIPR2, WRAP73. RRMS VS SPMS: ABCC5, AKAP12, CARS, CBFA2T3, CCDC67, FAM110A, FRMD4A, GIMAP5, HIVEP3, ICAM5, KCNQ1, KLF4, LEFTY2, OLFM3, PTH1R, RASA3, RNF39, RPH3AL, TRAF3, USP35, XKR5.

SRM, GNG12, GFI1, ANXA4, NFE2L2, ABLIM2, AHRR, SMIM3, CDKN1A TPST1, CNTNAP2, SNTG1, MTSS1, PTK2, ZC3H3, ZMIZ1, PTGDR2, PRSS23, GRIK4, ETV6, RARG, LOC348021, CCDC88C, ITPK1, ANPEP, RARA, SMIM6, RECQL5, F2RL3, LINC00111, ACOT9.

PAD2

MBP3, WM1. Methylation 450k Beadchip
ALDOA, ATP1A2, BCAR1, BRK1, CDK5, CORO1A, CSF3, DLC1, DTNBP1, FGD2, FMNL1, MLST8, MYBPC3, MYH6, MYH7, MYO1F, OBSCN, PDGFA, PRKCZ, SHC1, SIPA1L1, SSH3, TPM3, ADA, AGAP1, ALDOA, ARHGEF16, ATP1A1, ATP1A2, ATP1A4, ATP5H, BIN1, DAB2IP, DLC1, FGD2, LDHC, MACROD1, MLST8, MYBPC3, MYH6, MYH7, NME4, NT5C, PLXNB1, PTPRN2, RASA3, SEPT9, SIPA1L1, TBCD, TK1, ACSBG1, ACSL1, ACTR8, ADA, AGAP1, AGPAT1, AGRP, AKAP8, ALDH3A1, ALDOA, AMH, ANGPT2, APBB1IP, APEX, ARHGEF16, ATF6B, ATP11A, ATP1A1, ATP1A2, ATP1A4, ATP6V0E1, ATRIP, BBS2, BCAR1, BCL2L2, BIN1, BIRC5, BPI, BRD4, BRK1, C4B, CACNA1D, CASKIN1, CBX4, CCL17, CCL22, CD37, CD59, CDH1, CDK5, CHST3, CHURC1, CLASP1, CLIC5, CORO1A, CREB5, CRY2, CSF3, CSNK1E, CX3CL1, CXXC5, CYP21A2, DAB2IP, DAND5, DCPS, DHRS3, DLC1, DLL1, DOK4, DOT1L, DSCAML1, DTNBP1, DYRK1B, E2F6, E4F1, EDN2, EFS, ENTPD2, ERCC3, F7, FAM109A, FGD2, FGFR3, FMNL1, GBX1, GDF10, GPR114, GPR56, GTF2H1, GYLTL1B, HDAC11, HEG1, HEXIM1, HEXIM2, HIGD1A, HIST3H3, HLA-DMA, IL17RB, IL25, IL34, INO80E, INPP5J, INTS1, IRAK2, ITPKB, JARID2, LIMD1, LMF1, LPCAT1, MAB21L2, MADD, MAML3, MAP3K14, MAPK3, MBP, MCF2L, MED24, MEIS2, MLLT10, MLST8, MT1A, MT1E, MT1F, MT1G, MT1M, MT2A, MT4, MTCH1, MTSS1L, MUSK, MYBPC3, MYH6, MYH7, MYO1F, NARFL, NCOR2, NDRG1, NLRP3, NOTCH4, NR1H3, NUP210, OBSCN, OTX2, PABPN1, PAG1, 
Table 1 DNA methylation changes in MS (Continued)

References Comparison Sample Method

Differentially methylated genes

target
CD8+ $T$ cells Whole blood
RRMS vs PPMS vs SPMS vS CTR

MS vs CTR

MS treatment-naïve PMBCs vs 1 year IFN-b vs CTR

Discordant twins (RRMS vs CTR)

RRMS(e)vs RRMS(r) vs CTR

\section{RRMS vs CTR}

RRMS vs CTR

RRMS(e) vs RRMS(r) vs CTR

RRMS(e) vs RRMS(r) vs CTR

Whole Blood Discordant twins
Buffy coat

Whole blood PBMCs NAWM

CD4+ T cells RRBS

Serum

cfDNA (serum)

CD3+ T cells

cfDNA (plasma)

Illumina 450K array

BS-sequencing

Illumina $450 \mathrm{~K}$ array

BS-PCR sequencing assay

LINE-1

TMEM1, PEX14.

MOG

LINE-1

VDR

RRMS(r) vs CTR: CDH1, CDKN2A, CDKN2B, FAS, ICAM1, MCJ, MDGI, BRCA1, CCND2, DAPK, FAS, FHIT, MCT1, MDGI, MCJ, CDKN2A, TP73, PGK1, PR-PROX.RRMS(r) vs RRMS(e): CDH1, CDKN2B, HIC1, PR-PROX, SYK.

CDKN2A, SOCS1, RUNX3, NEUROG1. Ligation Probe Amplification PCR

PMBCs Bisulphite lllumina APC2, TMEM48, ANGPTL2, RALGPS1, USP29, C20orf151, DLL1 6, DACH2, INPP5A, LOC727677, SEMA5B, SUGT1L1, HOXB2, OR10J5, 源 (654342, ARHGEF17, DNHD1, KIF1C, INCA1, VSIG1. Whole blood: 源,

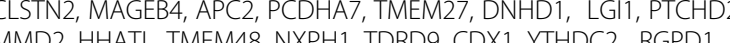
PLGLB2.

SHP-1

IL2RA

MethDet-56 microarray based assay

TMEM232, SEMA3C, YWHAGI, ZBTB16, MRI1. MUC2, MYF3, PAX5, PGK1, RB1, SOCS1, SYK, TP73. RRMS(e) vS CTR:

PBX2, PCSK6, PDGFA, PEG10, PHF21A, PIK3R1, PLEKHG3, PLLP, PRAM1, PRDM16, PRKCH, PRKCZ, PTGDS, PTPRN2, RAD9A, RAI1, RASA3, RBP1, RFX5, RIN2, RNF187, RPA1, RRM2, RXRA, SACS, SEMA4C, SETD1, SHC1, SHISA5, SIPA1L1, SLC17A7, SLC22A17, SLC39A13, SUN1, TACC 3, TPM3, TRAF2, TSNARE1, UBE2L3, USP19, VAC14, WHSC1, WISP1, WISP2, WNK2, ZBTB47, ZFP1, ZIC1, ZNF135, ZNF256, ZNF329, ZNF362, ZNF414, ZNF418, ZNF488, ZNF606, ZNF664, ZNF687, ADAMDEC1, AIF1, AIRE, B2M, BPI, C1QA, C1QB, C1QC, C4BPA, C4BPB, CCR6, CD19, CD37, CD4, CD7, CD81, CFD, DLG1, FCER2, HAMP, HLA-DMA, HLA-

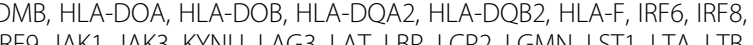
MBL2, MICB, NCR3, OSM, PSMB8, PTPN22, RARA, RNF31, SECTM1, SLAMF7, STXBP2, TAP1, TAP2, TAPBP, TNF, TNIP2, B2M, C1QA, C1QB, NCR3, SLAMF7, TAP1, TAP2, TNF, B2MLA-DMA, LAG3, LTA, MBL2, C4BPB, DLG1, FCER2, HLA-DMA, LAG3, LAT, LTA, MBL2, NCR3, SLAMF7, STXBP2, TAP1, TAP2, TNF, B2M, FCER2, HAMP, LAG3, MBL2, NCR3, SLAMF7, STXBP2, TAP1, TAP2, BHLHE23, CTSZ, DLG1, DLL1, DLX1, DLX2, EDARADD, EPHB4, FOXL2, GLI1, GNAS, HOXC11, HOXC13, HOXC4, HOXC8, HOXC9, HOXD10, HOXD11, HOXD13, HOXD3, HOXD4, HOXD8, HOXD9, MSX1, PHLDA2, PPP1R13L, PTCD2, , CD4+T cells: DCX, RDH13, DNHD1, TEKT5, TXNL1, MAGI2, TTC30B, RBMS1, C20orf151, AEN. CD8+T cells: APC2, HOXA2, HRNBP3, HEXDC, 
Table 1 DNA methylation changes in MS (Continued)

\begin{tabular}{|c|c|c|c|c|}
\hline References & Comparison & $\begin{array}{l}\text { Sample } \\
\text { target }\end{array}$ & Method & Differentially methylated genes \\
\hline & (MS vs CTR) & CD4+ T cells & Methylation 450k Beadchip & \\
\hline [59] & $\begin{array}{l}\text { RRMS and SPMS } \\
\text { vs CTR }\end{array}$ & PMBCs & BS-PCR sequencing assay & PAD2 \\
\hline$[60]$ & $\begin{array}{l}\text { RRMS and SPMS } \\
\text { vs CTR }\end{array}$ & PMBCs & EpiTyper assay & DNMT1, TET2 \\
\hline [61] & $\begin{array}{l}\text { RRMS vs SPMS } \\
\text { vs CTR }\end{array}$ & CD4+ T cells & Illumina 450K array & VMP1, MIR21 \\
\hline
\end{tabular}

MS multiple sclerosis, CTR control, RRMS relapsing-remitting multiple sclerosis, PPMS primary progressive multiple sclerosis, SPMS secondary progressive multiple sclerosis, RRMS(e) RRMS in exacerbation, RRMS(r) RRMS in remission, cfDNA circulating-free DNA, PBMCs peripheral blood mononuclear cells, BS bisulphite, RRBS reduced representation bisulphite sequencing, NAWM normal appearing white matter

RRMS patients [43]. This result suggests that an overactivation of the inflammatory response in MS may be attributable to the aberrant methylation pattern of certain anti-inflammatory genes.

\section{Demyelination}

In MS, demyelination occurs when the myelin sheath of neurons is damaged by the action of the immune system [72]. The attack of immune surveillance is mainly directed against the myelin basic protein (MBP) [73], a protein that stabilises and maintains the correct structure of the myelin sheath around the axon [74]. An extensive hippocampal demyelination simultaneously coincides with the lower number of methyl groups to the DNMT promoters with an increase in their mRNA levels and a decrease in their TET enzymes [41]. Under normal conditions, approximately $20 \%$ of the total MBP is citrullinated (MBP-Cit). Citrullination is a post-translational modification catalysed by peptidyl arginine deiminase 2 (PAD2) [75]. The addition of citrullin groups leads to the loss of myelin compaction [76], and particularly, the percentage of MBP-Cit increases drastically [77] along with the promoter demethylation and overexpression of PAD2 as a result of the clinical course [45, 59]. The processing of MBP self-antigens and their presentation by APCs to $\mathrm{T}$ cells occurs during the negative selection of autoreactive $\mathrm{T}$ cells in the thymus [78]. An increase in the legumain (LGMN) activity, an enzyme involved in the self-antigen processing, prevents the development of immune tolerance against MBP [79]. Interestingly, the demethylation of the LGMN promoter could be responsible for favouring autoimmunity in MS patients [47, 74].

\section{Remyelination failure}

Following the myelin destruction, the recruitment of oligodendrocyte progenitor cells (OPCs) is necessary to rescue the demyelinated axons [80]. However, in MS patients, this process is not completely achieved [81], contributing to progressive neurodegeneration. The origin of this failure is not fully understood, but some hypotheses have been postulated in this regard [81]. Briefly, remyelination may be incomplete because of the inadequate recruitment of OPCs into the demyelinated lesion, an impairment of the OPC differentiation into myelinating oligodendrocytes, or the dysfunctions in oligodendrocytes when they attempt to wrap axons $[81,82]$. In adults, OPC migration and recruitment require several growth factors including the plateletderived growth factor (PDGF) and the fibroblast growth factor (FGF) [83-85]. Both growth factors are significantly methylated in the NAWM of MS patients [47]. In this regard, the addition of methyl groups to the DNA may be accompanied by the lower expression of PDGF and FGF during disease progression, thus gaining mechanistic insight into the oligodendrocyte dysfunction. Wnt signalling pathway is involved in the differentiation of precursor oligodendocytes into mature myelinating oligodendocytes, affecting remyelination of axons [86]. Fancy et al. (2009) found that MS demyelinating lesions display an activation of the Wnt signalling impairing the remyelination process due to lack of proliferation of premyelinating oligodendrocytes [86]. Interestingly, some of the negative regulators of the Wnt pathway (histone deacetylase inhibitors, or Shisha genes) [87, 88] are hypermethylated in the brain [47, 41]. This hypermethylation would facilitate Wnt pathway activation declining efficiency of endogenous remyelination. This hypothesis is reinforced by Chen et al. (2011). They reported that mice lacking HDAC1/ 2 displayed severe myelin deficiency [89]. The hypermethylation of neurofascin (NFAS) has been related to the improper myelin wrapping of paranodal segments and might respond to the pathophysiological mechanisms underlying MS [90, 91]. Self-antibodies against NFAS have been detected in MS patients [92]. In the hippocampus while neurodegeneration is ongoing, Chomyk et al. (2017) reported a decrease in the WD repeat domain 81 and AT-hook transcription factor methylation status, which could lead to a lower mRNA expression and neuronal injury [41]. 


\section{Neurodegeneration}

Progressive axonal loss contributes to brain atrophy and neurological disability [93]. Kulakova et al. (2016) examined the DNAme of the peripheral blood mononuclear cells (PBMCs) collected from secondary progressive (SPMS) and RRMS patients, providing a time course DNAme pattern [43]. They found a cluster of 21 differentially methylated genes. Gene ontology analysis revealed that four of these genes are hypermethylated while neurodegeneration is ongoing and involved in biological processes, such as cell proliferation (PTH1R, CBFA2T3, KLF4) and nuclear factor $\kappa$-light-chain-enhancer of activated B cell (NF-k $\beta$ ) pathway (KLF4, TRAF3). NF- $k \beta$ is a pleiotropic regulator of neuroinflammation, neuronal protection and neurotoxicity [94] involved in distinct pathological events mediated by the glia once the earliest signs of MS are present [95]. During the course of neurodegeneration, an imbalance between the expression of enzymes participating in the addition and removal of methyl groups to the DNA has been reported in MS patients. Indeed, Fagone et al. (2016) found an upregulation of methyl CpG-binding protein 2 and 4 and a downregulation of enzymes such as TET3 and TDG in SPMS patients [92].

\section{Environmental and lifestyle risk factors}

The influence of the environment on MS pathophysiology has been largely studied in twins discordant for the disease [52]. This divergence has been attributed to the effect of environmental risk factors through epigenetic modifications [96]. Thus, Handel et al. (2010) reported an additive deleterious effect of smoking, ultraviolet (UV) exposure and HLA alleles on MS prevalence [20]. Scientific evidence shows that environmental factors, such as smoking, Epstein Barr infection, vitamin D level, organic solvent and chemical pollutant exposure, diet style, gut microbiota, exercise and stress, are involved in the development and/or course of MS (Fig. 3).

\section{Smoking}

Smoking confers the risk for developing MS, and it is associated with disease onset and progression [97]. Degelman and Herman (2017) found a significant association between smoking frequency and conversion from RRMS to SPMS forms [98]. Nearly 98 chemical compounds of tobacco, including nicotine, cyanide and nitric oxide, are hazardous [99]. For example, nicotine increases the permeability of the BBB [100] in the earlier stages of MS [101], cyanide contributes to CNS demyelination [102] and nitric oxide promotes neurodegeneration [103]. Tobacco contains dioxins that activate the aryl-hydrocarbon receptor pathway [104], which modulates neuroinflammation [105] and Th17 and Treg activities [106] becoming a key player in the MS aetiology and disease progression. A well-designed study performed by Zeilinger et al. (2013) reported the differences in the DNAme of current, former and never smokers [107]. They found that the aryl-hydrocarbon receptor repressor (AHRR) was highly demethylated among the current smokers, leading to the inhibition of AhR signalling pathway and thus enhancing neuroinflammatory and neurodegeneration events

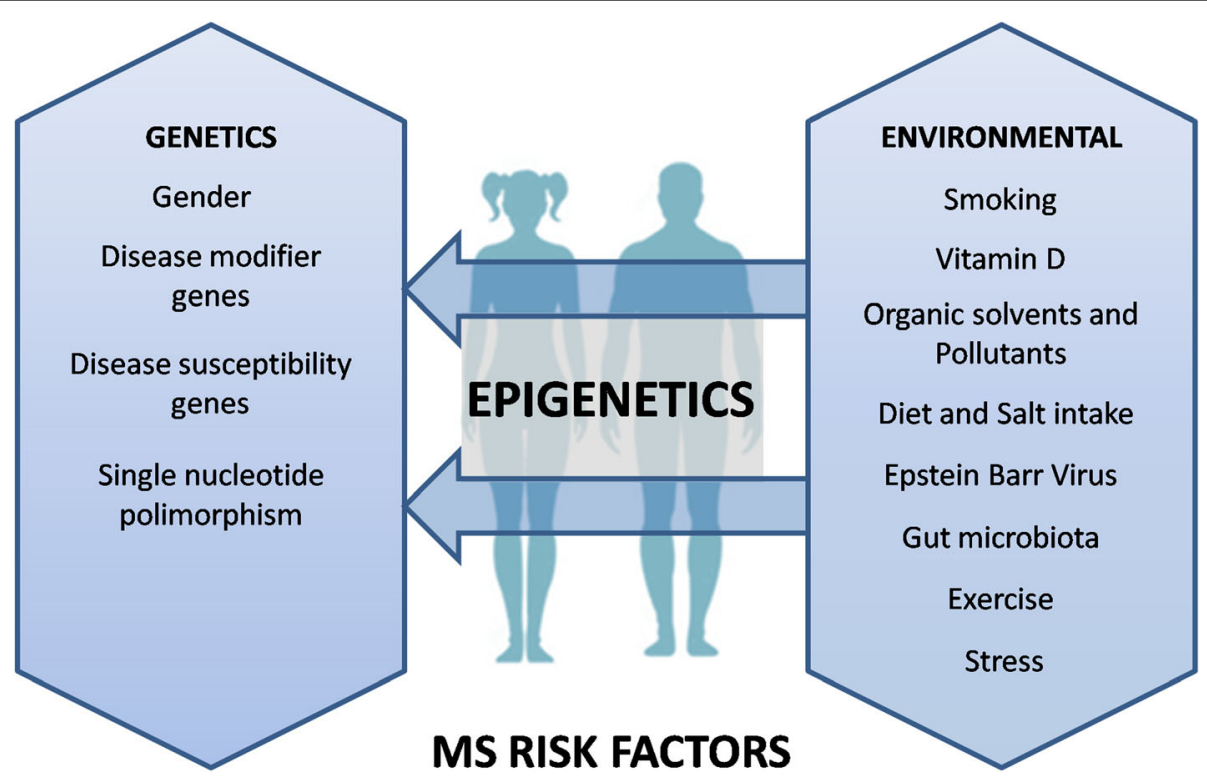

Fig. 3 Risk factors of multiple sclerosis. MS pathogenesis is influenced by both genetic and environmental factors. Among the genetic factors, gender, disease-modifier genes, disease susceptibility genes and single nucleotide polymorphisms are remarkably important in prevalence and MS pathogenesis. In contrast, environmental factors such as smoking, vitamin D deficiency, organic solvents and pollutants exposure, diet style, Epstein Barr infection, dysbiosis of the gut microbiota, lack of exercise and stress are critically associated with MS susceptibility and progression 
$[105,106]$. AhR can act as protective or deleterious pathway depending on the cell type where is expressed. In EAE model, AhR activation has a protective role in dendritic cells (DC), astrocytes and foxp3+ T reg cells, while it has a proinflammatory effect in Th17 cells [108]. AhR deletion is known to exacerbate EAE disease [109], altering myelinassociated proteins and increasing the production of proinflammatory cytokines [110]. In MS patients, low levels of AhR have been measured in serum, along with a reduced AhR activity in demyelinating lesions during disease progression [111]. Interestingly, Laquinimod, a phase III drug for MS treatment that activated AhR pathway, was shown to reduce brain atrophy in MS patients by counteracting the neuroinflammatory reaction [112].

\section{Epstein Barr virus}

The latent form of EBV is present in almost $90 \%$ of the world population within memory B cells [113]; more than 99\% of MS patients are seropositive for EBV [24]. Infection with EBV increases the risk of developing MS by $~ 3.6$-fold [114], and its effect can be exacerbated when interacts with other risk factor, such as HLA risk variants, rocketing the odd ratio for MS up to $\sim 15$-fold [115]. We can speculate that a cross-reaction may occur between the myelin self-antigens and certain viral proteins of the EBV in MS [116]. This hypothesis is underpinned by the identification of two EBV peptides (EBNA-1 and BRRF2) in the CSF of MS patients [117]. Indeed, the CD8+ T cells derived from MS patients displayed reactivity against some latent EBV proteins [117]. The reactivation of latent EBV in memory $\mathrm{B}$ cells may occur through specific epigenetic modifications. For example, the use of 5-azacytidine, a DNMT inhibitor, can switch the EBV latent form to a reactivated form [118].

\section{Vitamin D}

Vitamin D is synthesised upon exposure to UV [119] or can be obtained from diet [120]. Vitamin D deficiency is considered a risk factor for MS even before birth, altering the structure of embryonic tissues as a result of low maternal vitamin D [121]. Indeed, the prevalence of MS is lower near the equator, where UV radiation is at its maximum, than at higher and lower latitudes [122]. Low levels of vitamin D have been associated with a higher frequency of relapses [123] and disability [121].

Current evidence points out that the active form of vitamin $\mathrm{D}$ acts as an inducer of the promoter demethylation of multiple genes [124]. In accordance with these findings, Rawson et al. (2012) reported that a high intake of vitamin $\mathrm{D}$ is associated with lower methylation levels of certain genes involved in the Wnt signalling pathway [125], which could favour neurogenesis and neuronal plasticity [126]. In $T$ cells from RRMS whole peripheral blood, the vitamin $\mathrm{V}$ receptor (VDR) showed a promoter demethylation pattern associated with an overexpression of VDR mRNA [55]. Nevertheless, the underlying mechanism behind vitamin $\mathrm{D}$ and its effect on demethylation remains unknown and requires further investigation.

\section{Organic solvents and pesticides}

Organic solvents are hydrocarbon compounds commonly used worldwide. The prolonged exposure to these compounds has severe effects on health and may be clinically important in autoimmune diseases [127]. Organic solvents are highly hydrophilic and lipophilic molecules able to pass through the BBB into the brain, resulting in distinct myelin pathologies [128]. Exposure to organic solvents induces changes in the DNAme of the immune system [129] and certain genes involved in cell survival [130]. Hexachlorobenzene, a pesticide widely used until 1965, modulates the expression of E-cadherin through the activation of the integrin-linked kinase signalling [131]. Ecadherin plays an important role in BBB integrity, and its promoter region is highly methylated in MS patients [49], facilitating the infiltration of immune cell into the brain. To evaluate the precise contribution of this pesticide in the context of MS, we should determine the exposure time frame and if it occurred before or after the diagnosis of disease. Remarkably, the precise effect of organic solvents on DNAme in MS warrants further investigation. However, exposure to organic solvents and the presence of HLA risk alleles present a fourfold increased risk for MS in comparison with exposure to organic solvents alone, and the additive effect of organic solvents, HLA risk alleles and smoking increase the risk 20-fold [132].

\section{Diet}

Recent evidence points out that food intake is important in the pathogenesis of MS and other autoimmune diseases. Seasonal variations in food intake in pregnant mothers may interfere with foetal development and confer the risk of MS in the later life of the offspring (for a review, see [133]). The intake of some nutrients, such as long-chain fatty acids and salt, is known to act as proinflammatory molecules, whereas other nutrients, such as short-chain fatty acids and flavonoids, possess antiinflammatory properties [134]. A type of flavonoid called quercetin represses the capacity of monocytes to cross the BBB [135] and reduces the synthesis of proinflammatory cytokines produced by monocytes in MS [136]. Limited data are available on the intake of nutrients and their effect on DNAme. However, certain cofactors obtained from diet are required to maintain DNAme homeostasis. For example, vitamin B, folate, methionine, choline and zinc are essential to maintain the levels of Dnmt1 [137] and methyl-donor S-adenosylmethionine [137]. By contrast, vitamin C can act as a cofactor for 
TET enzymes [138]. In particular, vitamin $B_{12}$ is necessary for the proper function of the CNS through the conversion of homocysteine to methionine. Methionine regulates the expression of DNA methyltransferase 3A (DNMT3A) [139] and participates in the transcription of pro-inflammatory genes and the formation of myelin sheath [140]. Interestingly, vitamin $B_{12}$ and folate deficiency is reported in RRMS concomitantly with elevated levels of homocysteine. A misbalance in DNAme metabolism has been reported in MS patients [139, 141]. Indeed, some authors found that the levels of methyl group donors were lower in plasma [139] and postmortem grey matter [141] in MS.

The elevated consumption of salt has many noxious effects, including the production of reactive oxygen species [142], deregulation of regulatory $\mathrm{T}$ cells [143] and macrophage [144], disruption of BBB permeability [145] and higher probability of new brain lesions in RRMS patients [146]. After the ingestion of a diet containing high levels of salt, patients with an autoimmune disease showed demethylation and elevated levels of hydroxymethylation in CD4+ T cells as a result of TET2 overexpression [25]. Consequently, the high consumption of salt may be a risk factor for MS. Note that the use of standardised diets or alternative therapies cannot substitute conventional MS treatments, but the intake of healthy food may ameliorate the inflammatory and physical status of MS patients. Therefore, it can be hypothesised that some components of diet may interfere with the DNAme metabolism even before childbirth or during lifetime contributing to both disease aetiology and progression.

\section{Gut microbiota}

Gut microbiota is a complex ecosystem of microorganisms that establish a symbiotic relationship with the host by favouring the vitamin production and fermentation of some components of diet [147]. However, the dysbiosis of microbiota increases the risk of developing autoimmune diseases [148, 149]. DC from germ-free mice subjected to the EAE model were less reactive to stimulated proinflammatory $\mathrm{T}$ cells than conventionally colonised germ mice [149]. Berer et al. (2011) found that gut microbiota in cooperation with myelin auto-antigens is necessary to stimulate the immune response [148], consistent with [149]. Dysbiosis has been associated with an inflammatory phenotype in MS patients [150, 151]. Resident microbiota can alter the epigenetic signature of the host through the production of specific metabolites (Table 2). Pregnant women showed a different DNAme profile according to their predominant microbiota in the gut [166]. Therefore, dysbiosis of microbiota can be involved in disease onset by an overactivation of $\mathrm{T}$ cells $[148,149]$ or exacerbating inflammatory events in patients diagnosed with MS [150, 151]. However, the contribution of microbiota in disease aetiology and progression warrants further investigation.

Table 2 List of metabolites released by microbiota

\begin{tabular}{|c|c|}
\hline Metabolite & Effect on DNA methylation \\
\hline p-Cresol & $\begin{array}{l}\text { It induces the expression of DNA methyltransferases 1, 3a, and } 3 b \text { and it is associated with CpG hypermethylation of Klotho } \\
\text { gene [152], a regulator of vitamin D metabolism [153]. }\end{array}$ \\
\hline $\begin{array}{l}\text { Hydrogen sulphide } \\
\left(\mathrm{H}_{2} \mathrm{~S}\right)\end{array}$ & Involved in the neutralisation of ROS. It increases DNA methylation [154]. \\
\hline $\begin{array}{l}\text { Riboflavin (vitamin } B_{2} \text { ) } \\
\text { Pyridoxine (vitamin } \\
B_{6} \text { ) } \\
\text { Cobalamin (vitamin } \\
B_{12} \text { ) }\end{array}$ & Cofactor involved in DNA methylation metabolism $[155,156]$. \\
\hline Folate (vitamin $B_{9}$ ) & $\begin{array}{l}\text { It acts as a methyl donor involved in DNA methylation metabolism }[155,156] . \\
\text { It reduces the activity of DNA methyltransferase [157]. }\end{array}$ \\
\hline Choline & $\begin{array}{l}\text { It acts as a methyl donor that can be recruited by human gut microbiota, reducing its availability [158]. } \\
\text { Involved in DNA methylation and gene expression in murine colitis model, an inflammatory disease [159]. }\end{array}$ \\
\hline Betaine & $\begin{array}{l}\text { It acts as a methyl donor involved in DNA methylation reactions }[156,160] \\
\text { Associated with changes in DNA methyltransferases and coupled with changes in DNA methylation [161]. }\end{array}$ \\
\hline Ammonium $\left(\mathrm{NH}_{4}\right)$ & Inverse correlation between faecal $\mathrm{NH}_{3}$ and LINE-1 gene methylation [162]. \\
\hline a-ketoglutarate & Involved in (de)methylation as a co-factor of histone demethylases and TET family $[163,164]$. \\
\hline $\begin{array}{l}\text { L-ascorbic acid } \\
\text { (vitamin C) }\end{array}$ & $\begin{array}{l}\text { It exerts a strong influence on active DNA demethylation. It enhances TET-mediated generation of 5-hydroxymethylation } \\
\text { [165]. }\end{array}$ \\
\hline
\end{tabular}

ROS reactive oxygen species, $\mathrm{NH}_{3}$ ammonia, LINE-1 long interspersed element-1, TET ten-eleven translocation Adapted from Mischke et al. [147] 


\section{Physical activity}

Physical exercise has been demonstrated to produce changes in the leukocyte DNAme pattern [167] and thus changes in gene expression [168]. In the context of neurodegenerative diseases, the influence of physical exercise has a direct effect on the brain-derived neurotrophic factor (BDNF) [169, 170]. In a healthy brain, BDNF is mainly expressed in neurons [171]. However, following a demyelinating insult, this gene is transcriptionally active in astrocytes [172], regulatory T cells, B cells and monocytes [172, 173], favouring brain plasticity [174] and myelin formation [175]. Recently, Briken et al. (2016) found elevated protein levels of serum BDNF after 30 min of exercise in progressive MS patients [170], and this result was probably attributable to the demethylation of its promoter region [169]. Similarly, 2 weeks of physical exercise promotes the overexpression of TET1 and the demethylation of the vascular endothelial growth factor A (VEGF-A) [176]. VEGF-A may potentiate neurogenesis and neuroprotection in the EAE model as postulated by [177]. The overexpression of apoptosisassociated, speck-like protein containing a C-terminal caspase recruitment domain gene (ASC) activates inflammatory signalling and may exacerbate MS progression [178]. In addition, Nakajima et al. (2010) found that following 6 months of moderate exercise, the mRNA levels of ASC were lower because its promoter region was hypermethylated [179]. Therefore, the current data support the notion that moderate exercise can reduce pro-inflammatory cytokines and improve the clinical MS course. However, some studies failed to validate this evidence [180-182]. The findings reported here point out that moderate exercise can ameliorate some symptoms but cannot stop the progression of MS.

\section{Stress}

Stressful life events have a negative effect on MS by increasing the risk of clinical exacerbation and disease progression [183]. However, the contribution of stress in the pathophysiology of the disease remains under discussion. A well-designed study by Liu et al. (2009) reported a strong association between stress and MS aetiology [184]. In accordance with these findings, Babenko et al. (2015) demonstrated that prenatal stress causes a demethylation of the nuclear subfamily 3 group $C$ member 1 glucocorticoid receptor (NR3C1) [185] and changes in the nervous, immune and musculoskeletal systems [186]. Interestingly, the differences in NR3C1 gene expression have been reported in MS patients [187], suggesting that early life stressors can present susceptibility to developing MS in adulthood.

\section{DNA methylation in animal models of MS}

None of the current experimental animal models can reproduce the complexity and heterogeneity of MS. In particular, both disease onset and clinical course in animals differ considerably from those in humans [188]. However, in vivo experimental models are widely used to understand certain aspects of the disease. In general, we consider three models to study MS pathophysiology: (a) EAE, (b) Theiler's murine encephalomyelitis virus (TMEV) and (c) use of toxins such as cuprizone (CPZ) or lysolecithin. However, not all of them have been addressed to study the changes in DNAme. For example, no current study has been conducted on DNAme in the TMEV model.

\section{EAE model}

EAE is a well-established model of autoimmunity induced by the subcutaneous injection of self-antigens derived from myelin proteins, such as the myelin oligodendrocyte glycoprotein (MOG) [189] and the proteolipid protein (PLP) [190]. Catanzaro et al. (2016) characterised the DNAme profile in the striatum of EAE mice showing a global DNA hypomethylation of interneurons positive for neuronal nitric oxide synthase [191]. Interestingly, they found a demethylation of Rasrelated protein-1 (Dexras-1) in parallel with elevated levels of iron inside the cells and thus neurotoxicity and neuronal death. Furthermore, they reported that the hypomethylation of Dexras-1 was reverted when mice were subjected to an enriched environment in their home cage, emphasising an epigenetic-mediated effect [191]. Recently, Noori-Zadeh et al. (2017) found that the promoter region for forkhead box P3 was hypermethylated in T cells collected from EAE mice [192], thus indicating a dysfunction of regulatory $\mathrm{T}$ lineage and the lack of auto-immune tolerance [193].

\section{Toxin-induced demyelination}

Demyelination can be induced by copper-chelating agents (e.g. CPZ) or lysolecithin [194]. In the CPZ model, young adult mice fed with this neurotoxicant showed a significant loss of mature oligodendrocytes, astrocytosis, microgliosis and demyelination, followed by spontaneous remyelination [195]. The CPZ model was used by Olsen et al. (2019) to identify novel biomarkers related to the demyelination course [53]. Specifically, they isolated circulating-free DNA from mice blood at the end of the CPZ treatment, and identified a specific methylation pattern associated with oligondendrocyte apoptosis. Conversely, the use of lysolecithin in mice induced demyelination accompanied by a high expression of DNMT1 in the OPCs at the early stages of remyelination. By contrast, DNMT3A is highly expressed in oligodendrocytes at the later stages when remyelination is achieved. The study revealed a global hypermethylation in 
the oligodendrocyte lineage during remyelination, demonstrating that DNMT1 plays a crucial role in the proliferation and differentiation of OPCs into mature oligodendrocytes, while DNMT3A has a dominant role in the remyelination phase [196].

\section{Conclusions}

MS is an inflammatory autoimmune disease of the CNS caused by a complex interaction between genetic and environmental factors [20]. Emerging evidence indicates that DNAme actively participates in gene $\mathrm{x}$ environment interactions [33]. As previously mentioned, several studies showed an aberrant DNAme profile in relapsing-remitting forms and in progressive MS forms. Remarkably, most of the studies reported in this work were based on the bisulphite technique (Table 1). However, this approximation does not discriminate between 5-methylcytosine and 5-hydroxymethylcytosine and thus may contribute to a misinterpretation of the data. To avoid this bias, we recommend an alternative method for studying DNAme, such as the methylatedDNA immunoprecipitation and the TET-assisted bisulphate sequencing. As far as we know, genetic factors can explain approximately $30 \%$ of worldwide MS prevalence [23], and the remaining $70 \%$ may correspond to the influence of environmental risk factors. As described in this study, UV radiation, cigarette smoking and infection with the Epstein Barr virus are clinically relevant for MS, although other environmental factors, such as diet style, microbiota profile, exposure to organic solvents and pollutants, exercise and long-term stress, have a clear effect in MS. All of the aforementioned risk factors can modify the DNAme pattern in humans, but further studies are required to expand our knowledge of the molecular basis of the disease and elucidate the underlying mechanisms behind MS pathophysiology. Furthermore, DNA methylation is currently the best surrogate marker for epigenetic change in disease, because methylation alterations track with disease state. DNA methylation markers can also indicate success or failure of drug treatment, are stable in isolated DNA, and can be measured by a variety of quantitative and qualitative methods. We postulate that epigenetic DNAme marks described in the context of the disease can potentially be used in a specific, substantial, and credible way in clinical interventions. It is conceivable that, in the near future, we will be able to design drugs modifying DNAme metabolism to stop the progression of MS.

\section{Abbreviations}

5caC: 5-Carboxylcytosine; 5fC: 5-Formylcytosine; 5hmC: 5-

Hydroxymethylcytosine; $5 \mathrm{hmU}$ : 5-Hydroxymethyluracil; $5 \mathrm{mC}$ : 5 -

Methylcytosine; AHRR: Aryl-hydrocarbon receptor repressor; APC: Antigen

presenting cells; ASC: Apoptosis-associated speck-like protein containing a C- terminal caspase recruitment domain; BBB: Blood-brain barrier; BDNF: Brainderived neurotrophic factor; BER: Base excision repair; BS: Bisulphite; $\mathrm{CDH1}$ : Ecadherin; cfDNA: Circulating-free DNA; Cit: Citrullination; CNS: Central nervous system; CPZ: Cuprizone; CSF: Cerebrospinal fluid; CTR: Control;

CYP1A1: Cytochrome P450 family 1 subfamily A member 1; DC: Dendritic cell; Dexras-1: Ras-related protein-1; DNAme: DNA methylation; DNMT: DNA methyltransferases; EAE: Experimental autoimmune/allergic encephalomyelitis; EBV: Epstein Barr virus; FGF: Fibroblast growth factor; FOXP3: Forkhead box P3; $\mathrm{H}_{2} \mathrm{~S}$ : Hydrogen sulphide; HCB: Hexachlorobenzene; HDACs: Histone deacetylase inhibitors; HLA: Human leukocyte antigen; ICAM: Intercellular adhesion molecules; IFN-y: Interferon-gamma;

ILK: Integrin-linked kinase; LCFA: Long-chain fatty acids; LGMN: Legumain; LINE-1: Long interspersed element-1; MBD: Methyl CpG-binding protein; MBP: Myelin basic protein; MeDIP: Methylated-DNA immunoprecipitation; MHC: Major histocompatibility complex; MICB: MHC class I polypeptiderelated sequence B; MOG: Myelin oligodendrocyte glycoprotein; MS: Multiple sclerosis; NaCl: Salt; NAWM: Normal appearing white matter;

NFAS: Neurofascin; NF-kß: Nuclear factor k-light-chain-enhancer of activated $\mathrm{B}$ cells; $\mathrm{NH}_{3}$ : Ammonia; $\mathrm{NH}_{4}$ : Ammonium; NKRs: Natural killer receptors; nNOS: Neuronal nitric oxide synthase; NR3C1: Nuclear subfamily 3 group C member 1 glucocorticoid receptor; OPCs: Oligodendrocyte progenitor cells; PAD2: Peptidil arginine deiminase 2; PBMCs: Peripheral blood mononuclear cells; PDGF: Platelet-derived growth factor; PLP: Proteolipid protein; PPMS: Primary progressive multiple sclerosis; ROS: Reactive oxygen species; RRBS: Reduced representation bisulphite sequencing; RRMS(r): RRMS in remission; RRMS: Relapsing-remitting multiple sclerosis; RRMS(e): RRMS in exacerbation; SAM: Methyl-donor S-adenosylmethionine; SCFA: Short-chain fatty acids; SHP-1: Src homology region 2 domain-containing phosphatase-1; SOCS1: Suppressor of cytokine signalling 1; SPMS: Secondary progressive multiple sclerosis; TAB-seq: TET-assisted bisulphate sequencing; TCRs: T cell receptors; TDG: Thymine DNA glycosylase; TET: Ten-eleven translocation; Th: T helper; TMEV: Theiler's murine encephalomyelitis virus; VDR: Vitamin D receptor; VEGF-A: Vascular endothelial growth factor A; Vit D: Vitamin D

\section{Acknowledgements}

Not applicable.

\section{Authors' contributions}

NC and JTR researched the literature and drafted the manuscript. JTR critically reviewed and edited the work. Both authors read and approved the final manuscript.

\section{Funding}

The authors disclosed receipt of the following financial support for the research, authorship, and/or publication of this article: This review was funded by the Deutsche Forschungsgemeinschaft to Dr. Jordi Tomas Roig (ref. TO 977/1-1) and the University of Girona to Mrs Naiara Celarain Sanz (ref. IFUdG2017)

\section{Availability of data and materials}

The authors confirm that the data supporting the findings of this study are available within the manuscript.

Ethics approval and consent to participate Not applicable.

\section{Consent for publication}

All authors read and approved the final manuscript.

\section{Competing interests}

The authors declare that they have no competing interests.

Received: 3 August 2019 Accepted: 27 November 2019

Published online: 14 January 2020

\section{References}

1. Ghasemi N, Razavi S, Nikzad E. Multiple sclerosis: pathogenesis, symptoms, diagnoses and cell-based therapy citation. Cell J. 2017;19:1-10.

2. De Stefano N, Narayanan S, Francis GS, Arnaoutelis R, Tartaglia MC, Antel JP, et al. Evidence of axonal damage in the early stages of multiple sclerosis and its relevance to disability. Arch Neurol. 2001;58:65-70. 
3. Compston A, Coles A. Seminar multiple sclerosis; 2008

4. Jennum P, Wanscher B, Frederiksen J, Kiellberg J. The socioeconomic consequences of multiple sclerosis: a controlled national study. Eur Neuropsychopharmacol. 2012; 22:36-43. https://doi.org/10.1016/.j.euroneuro.2011.05.001.

5. Gandhi R, Laroni A, Weiner HL. Role of the innate immune system in the pathogenesis of multiple sclerosis. J Neuroimmunol. 2010;221:7-14. https:// doi.org/10.1016/j.jneuroim.2009.10.015.

6. Sattler A, Wagner U, Rossol M, Sieper J, Wu P, Krause A, et al. Cytokineinduced human IFN- - -secreting effector-memory Th cells in chronic autoimmune inflammation. Blood. 2009;113:1948-56.

7. Young HA, Hardy KJ. Role of interferon- $\gamma$ in immune cell regulation. J Leukoc Biol. 1995;58:373-81.

8. Takeshita Y, Ransohoff RM. Inflammatory cell trafficking across the bloodbrain barrier: chemokine regulation and in vitro models. Immunol Rev. 2012; 248:228-39.

9. Louveau A, Harris TH, Kipnis J. Revisiting the concept of CNS immune privilege. Trends Immunol. 2016;36:569-77. https://doi.org/10.1016/j.it.2015. 08.006.Revisiting

10. Leech S, Kirk J, Plumb J, McQuaid S. Persistent endothelial abnormalities and blood-brain barrier leak in primary and secondary progressive multiple sclerosis. Neuropathol Appl Neurobiol. 2007:33:86-98.

11. Larochelle C, Alvarez JI, Prat A. How do immune cells overcome the bloodbrain barrier in multiple sclerosis? FEBS Lett. 2011;585:3770-80. https://doi. org/10.1016/j.febslet.2011.04.066.

12. Cao Y, Goods BA, Raddassi K, Nepom GT, Kwok WW, Love JC, et al. Distinct inflammatory profiles of myelin-reactive $t$ cells from patients with multiple sclerosis HHS Public Access. Sci Transl Med. 2015;7:287-74. https://doi.org/ 10.1126/scitranslmed.aaa8038.

13. Chitnis $T$. The role of CD4 T cells in the pathogenesis of multiple sclerosis. Int Rev Neurobiol. 2007;79:43-72.

14. Correale J, Farez MF, Cardona AE. The role of astrocytes in multiple sclerosis progression. Front Neurol. 2015;6:180.

15. Najafi S, Mirshafiey A. The effect of activated microglia in progression of multiple sclerosis. Int Trends Immun. 2015;3:96-104.

16. Denic A, Wootla B, Rodriguez M. CD8 ${ }^{+} \mathrm{T}$ cells in multiple sclerosis. Expert Opin Ther Targets. 2013;17:1053-66.

17. Krumbholz M, Derfuss T, Hohlfeld R, Meinl E. B cells and antibodies in multiple sclerosis pathogenesis and therapy. Nat Rev Neurol. 2012;8:613-23. https://doi.org/10.1038/nrneurol.2012.203.

18. Jelcic I, Al Nimer F, Wang J, Lentsch V, Planas R, Jelcic I, et al. Memory B cells activate brain-homing, autoreactive CD4+ T cells in multiple sclerosis. Cell. 2018;175:85-100 e23.

19. Stassart RM, Möbius W, Nave KA, Edgar JM. The axon-myelin unit in development and degenerative disease. Front Neurosci. 2018;12:467.

20. Handel AE, Handunnetthi L, Giovannoni G, Ebers GC, Ramagopalan S V. Genetic and environmental factors and the distribution of multiple sclerosis in Europe. Eur J Neurol. 2010;17:1210-4.

21. Meaney MJ. Epigenetics and the biological definition of gene $X$ environment interactions. Child Dev. 2010;81:41-79.

22. Gourraud PA, Harbo HF, Hauser SL, Baranzini SE. The genetics of multiple sclerosis: an up-to-date review. Immunol Rev. 2012;248:87-103.

23. Lill CM. Recent advances and future challenges in the genetics of multiple sclerosis. Front Neurol. 2014:5:1-5.

24. Ascherio A, Munger KL. Environmental risk factors for multiple sclerosis. Part I: the role of infection. Ann Neurol. 2007:61:288-99.

25. Wu H, Huang X, Qiu H, Zhao M, Liao W, Yuan S, et al. High salt promotes autoimmunity by TET2-induced DNA demethylation and driving the differentiation of Tfh cells. Sci Rep. 2016;6:1-14.

26. Allis $C D$, Jenuwein $T$. The molecular hallmarks of epigenetic control. Nat Rev Genet. 2016;17:487-500. https://doi.org/10.1038/nrg.2016.59.

27. Ehrlich M, Gama-Sosa MA, Huang LH, Midgett RM, Kuo KC, Mccune RA, et al. Amount and distribution of 5-methylcytosine in human DNA from different types of tissues or cells. Nucleic Acids Res. 1982;10:2709-21.

28. Weber M, Hellmann I, Stadler MB, Ramos L, Pääbo S, Rebhan M, et al. Distribution, silencing potential and evolutionary impact of promoter DNA methylation in the human genome. Nat Genet. 2007:39:457-66.

29. Svedružić ŽM. Dnmt1: Structure and function. Prog Mol Biol Transl Sci. 2011; 101:221-54

30. Mortusewicz O, Schermelleh L, Walter J, Cardoso MC, Leonhardt H. Recruitment of DNA methyltransferase I to DNA repair sites. Proc Natl Acad Sci. 2005;102:8905-9. https://doi.org/10.1073/pnas.0501034102.
31. Van Emburgh $\mathrm{BO}$, Robertson $\mathrm{KD}$. Modulation of Dnmt3b function in vitro by interactions with Dnmt3L, Dnmt3a and Dnmt3b splice variants. Nucleic Acids Res. 2011;39:4984-5002.

32. Lienert F, Wirbelauer C, Som I, Dean A, Mohn F, Schübeler D. Identification of genetic elements that autonomously determine DNA methylation states. Nat Genet. 2011:43:1091-7. https://doi.org/10.1038/ng.946.

33. Flores KB, Wolschin F, Amdam GV. The role of methylation of DNA in environmental adaptation. Integr Comp Biol. 2013;53:359-72.

34. Kagiwada S, Kurimoto K, Hirota T, Yamaji M, Saitou M. Replication-coupled passive DNA demethylation for the erasure of genome imprints in mice. EMBO J. 2013:32:340-53.

35. Ito S, Dalessio AC, Taranova OV, Hong K, Sowers LC, Zhang Y. Role of tet proteins in $5 \mathrm{mC}$ to $5 \mathrm{hmC}$ conversion, ES-cell self-renewal and inner cell mass specification. Nature. 2010;466:1129-33. https://doi.org/10.1038/nature09303.

36. Ito S, Shen L, Dai Q, Wu SC, Collins LB, Swenberg JA, et al. Tet proteins can convert 5-Methylcytosine to 5-Formylcytosine and 5-Carboxylcytosine. Science. 2011:333:1300-3.

37. Guo JU, Su Y, Zhong C, Ming GL, Song H. Hydroxylation of 5-methylcytosine by TET1 promotes active DNA demethylation in the adult brain. Cell. 2011; 145:423-34. https://doi.org/10.1016/j.cell.2011.03.022.

38. Cortellino S, Xu J, Sannai M, Moore R, Caretti E, Cigliano A, et al. Thymine DNA glycosylase is essential for active DNA demethylation by linked deamination-base excision repair. Cell. 2011;146:67-79.

39. Maltby VE, Graves MC, Lea RA, Benton MC, Sanders KA, Tajouri L, et al. Genome-wide DNA methylation profiling of CD8+ T cells shows a distinct epigenetic signature to CD4+ T cells in multiple sclerosis patients. Clin Epigenetics. 2015;7:1-6. http://dx.doi.org/10.1186/s13148-015-0152-7

40. Graves MC, Benton M, Lea RA, Boyle M, Tajouri L, Macartney-Coxson D, et al. Methylation differences at the HLA-DRB1 locus in CD4+ T-cells are associated with multiple sclerosis. Mult Scler J. 2014;20:1033-41.

41. Chomyk AM, Volsko C, Tripathi A, Deckard SA, Trapp BD, Fox RJ, et al. DNA methylation in demyelinated multiple sclerosis hippocampus. Sci Rep. 2017;7: 1-10. http://dx.doi.org/10.1038/s41598-017-08623-5.

42. Fagone P, Mangano K, di Marco R, Touil-Boukoffa C, Chikovan T, Signorelli S, et al. Expression of DNA methylation genes in secondary progressive multiple sclerosis. J Neuroimmunol. 2016;290:66-9.

43. Kulakova OG, Kabilov MR, Danilova LV, Popova EV, Baturina OA, Tsareva EY, et al. Whole-genome DNA methylation analysis of peripheral blood mononuclear cells in multiple sclerosis patients with different disease courses. Acta Naturae. 2016:8:103-10.

44. Marabita F, Almgren M, Sjöholm LK, Kular L, Liu Y, James T, et al. Smoking induces DNA methylation changes in multiple sclerosis patients with exposure-response relationship. Sci Rep. 2017;7:1-15.

45. Mastronardi FG, Noor A, Wood DD, Paton T, Moscarello MA. Peptidyl argininedeiminase $2 \mathrm{CpG}$ island in multiple sclerosis white matter is hypomethylated. J Neurosci Res. 2007;85:2006-16.

46. Lehmann-Werman R, Neiman D, Zemmour H, Moss J, Magenheim J, VakninDembinsky A, et al. Identification of tissue-specific cell death using methylation patterns of circulating DNA. Proc Natl Acad Sci. 2016;113: e1826-34. http://dx.doi.org/10.1073/pnas.1519286113.

47. Huynh JL, Garg P, Thin TH, Yoo S, Dutta R, Trapp BD, et al. Epigenome-wide differences in pathology-free regions of multiple sclerosis-affected brains. Nat Neurosci. 2014;17:121-30. https://doi.org/10.1038/nn.3588.

48. Bos SD, Page CM, Andreassen BK, Elboudwarej E, Gustavsen MW, Briggs F, et al. Genome-wide DNA methylation profiles indicate CD8+ T cell hypermethylation in multiple sclerosis. PLoS One. 2015;10:1-16.

49. Kumagai C, Kalman B, Middleton FA, Vyshkina T, Massa PT. Increased promoter methylation of the immune regulatory gene SHP-1 in leukocytes of multiple sclerosis subjects. J Neuroimmunol. 2012;246:51-7. https://doi. org/10.1016/j.jneuroim.2012.03.003

50. Field J, Fox A, Jordan MA, Baxter AG, Spelman T, Gresle M, et al. Interleukin-2 receptor-a proximal promoter hypomethylation is associated with multiple sclerosis. Genes Immun. 2017;18:59-66. http://dx.doi.org/10.1038/gene.2016.50

51. Pinto-Medel MJ, Oliver-Martos B, Urbaneja-Romero P, Hurtado-Guerrero I, Ortega-Pinazo J, Serrano-Castro P, et al. Global methylation correlates with clinical status in multiple sclerosis patients in the first year of IFNbeta treatment. Sci Rep. 2017;7:1-9.

52. Baranzini SE, Mudge J, Van Velkinburgh JC, Khankhanian P, Khrebtukova I, Miller NA, et al. Genome, epigenome and RNA sequences of monozygotic twins discordant for multiple sclerosis. Nature. 2010;464:1351-6. http://dx. doi.org/10.1038/nature08990. 
53. Olsen JA, Kenna LA, Tipon RC, Spelios MG, Stecker MM, Akirav EM. A minimally-invasive blood-derived biomarker of oligodendrocyte cell-loss in multiple sclerosis. EBioMedicine. 2016;10:227-35.

54. Dunaeva M, Derksen M, Pruijn GJM. LINE-1 Hypermethylation in serum cellfree DNA of relapsing remitting multiple sclerosis patients. Mol Neurobiol. 2018;55:4681-8.

55. Ayuso T, Aznar P, Soriano L, Olaskoaga A, Roldán M, Otano M, et al. Vitamin $D$ receptor gene is epigenetically altered and transcriptionally up-regulated in multiple sclerosis. PLoS One. 2017;12:1-10.

56. Liggett T, Melnikov A, Tilwalli S, Yi Q, Chen H, Replogle C, et al. Methylation patterns of cell-free plasma DNA in relapsing-remitting multiple sclerosis. J Neurol Sci. 2010;290:16-21. https://doi.org/10.1016/j.jns.2009.12.018.

57. Sokratous M, Dardiotis E, Bellou E, Tsouris Z, Michalopoulou A, Dardioti M, et al. CpG island methylation patterns in relapsing-remitting multiple sclerosis. J Mol Neurosci. 2018;64:478-84.

58. Souren NY, Gerdes LA, Lutsik P, Gasparoni G, Beltran E, Salhab A, et al. DNA methylation signatures of a large cohort monozygotic twins clinically discordant for multiple sclerosis; 2018. http://dx.doi.org/10.1101/381822.

59. Calabrese R, Zampieri M, Mechelli R, Annibali V, Guastafierro T, Ciccarone F, et al. Methylation-dependent PAD2 upregulation in multiple sclerosis peripheral blood. Mult Scler J. 2012;18:299-304.

60. Calabrese R, Valentini E, Ciccarone F, Guastafierro T, Bacalini MG, Ricigliano VAG, et al. TET2 gene expression and 5-hydroxymethylcytosine level in multiple sclerosis peripheral blood cells. Biochim Biophys Acta - Mol Basis Dis. 1842;2014:1130-6.

61. Ruhrmann S, Ewing E, Piket E, Kular L, Cetrulo Lorenzi JC, Fernandes SJ, et al. Hypermethylation of MIR21 in CD4+ T cells from patients with relapsingremitting multiple sclerosis associates with lower miRNA-21 levels and concomitant up-regulation of its target genes. Mult Scler J. 2017;24: 1288-1300.

62. Hemmer B, Cepok S, Zhou D, Sommer N. Multiple sclerosis -- a coordinated immune attack across the blood brain barrier 2. Curr Neurovasc Res. 2004;1: 141-50. https://doi.org/10.2174/1567202043480152.

63. On NH, Kiptoo P, Siahaan TJ, Miller DW. Modulation of blood-brain barrier permeability in mice using synthetic E-cadherin peptide. Mol Pharm. 2014; 11:974-81.

64. Montesinos ML. Cell adhesion molecules: implications in neurological diseases; 2014

65. Greenwood J, Heasman SJ, Alvarez JI, Prat A, Lyck R, Engelhardt B. Review: Leucocyte-endothelial cell crosstalk at the blood-brain barrier: a prerequisite for successful immune cell entry to the brain. Neuropathol Appl Neurobiol. 2011;37:24-39.

66. Bullard DC, Hu X, Schoeb TR, Collins RG, Beaudet AL, Barnum SR. Intercellular adhesion molecule-1 expression is required on multiple cell types for the development of experimental autoimmune encephalomyelitis. J Immunol. 2007;178:851-7. https://doi.org/10.4049/jimmunol.178.2.851.

67. Dulberger CL, McMurtrey CP, Hölzemer A, Neu KE, Liu V, Steinbach AM, et al. Human leukocyte antigen $\mathrm{F}$ presents peptides and regulates immunity through interactions with NK cell receptors. Immunity. 2017;46:1018-29 e7.

68. Frohn C, Fricke L, Puchta JC, Kirchner H. The effect of HLA-C matching on acute renal transplant rejection. Nephrol Dial Transplant. 2001;16:355-60.

69. Meresse B, Curran SA, Ciszewski C, Orbelyan G, Setty M, Bhagat G, et al. Reprogramming of CTLs into natural killer-like cells in celiac disease. J Exp Med. 2006;203:1343-55. https://doi.org/10.1084/jem.20060028.

70. Yoshihara Y, Oka S, Nemoto Y, Watanabe Y, Nagata S, Kagamiyama H, et al. An ICAM-related neuronal glycoprotein, telencephalin, with brain segmentspecific expression. Neuron. 1994;12:541-53.

71. Paetau S, Rolova T, Ning L, Gahmberg CG. Neuronal ICAM-5 inhibits microglia adhesion and phagocytosis and promotes an anti-inflammatory response in LPS stimulated microglia. Front Mol Neurosci. 2017;10:1-12. https://doi.org/10.3389/fnmol.2017.00431.

72. Lubetzki C, Stankoff B. Demyelination in multiple sclerosis. Handb Clin Neurol. 2014;122:89-99. http://sci-hub.tw/10.1016/B978-0-444-52001-2. 00004-2.

73. Karin N. Reversal of experimental autoimmune encephalomyelitis by a soluble peptide variant of a myelin basic protein epitope: T cell receptor antagonism and reduction of interferon gamma and tumor necrosis factor alpha production. J Exp Med. 2004;180:2227-37.

74. Krogsgaard M, Wucherpfennig KW, Cannella B, Hansen BE, Svejgaard A, Pyrdol J, et al. Visualization of myelin basic protein (Mbp) T cell epitopes in multiple sclerosis lesions using a monoclonal antibody specific for the human histocompatibility leukocyte antigen (Hla)-Dr2-Mbp 85-99 complex. J Exp Med. 2000;191:1395-412.

75. Falcão AM, Meijer M, Scaglione A, Rinwa P, Agirre E, Liang J, et al. PADI2mediated citrullination is required for efficient oligodendrocyte differentiation and myelination. bioRxiv. 2018. https://doi.org/10.1101/425348.

76. Pritzker LB, Joshi S, Harauz G, Moscarello MA. Deimination of myelin basic protein. 2. Effect of methylation of MBP on its deimination by peptidylarginine deiminase. Biochemistry. 2000;39:5382-8.

77. Wood DD, Bilbao JM, O'Connors P, Moscarello MA. Acute multiple sclerosis (Marburg type) is associated with developmentally immature myelin basic protein. Ann Neurol. 1996;40:18-24.

78. Watts C, Matthews SP, Mazzeo D, Manoury B, Moss CX. Asparaginyl endopeptidase: case history of a class II MHC compartment protease. Immunol Rev. 2005;207:218-28.

79. Manoury B, Mazzeo D, Fugger L, Viner N, Ponsford M, Streeter H, et al. Destructive processing by asparagine endopeptidase limits presentation of a dominant T cell epitope in MBP. Nat Immunol. 2002:3:169-74.

80. Wolswijk G. Chronic stage multiple sclerosis lesions contain a relatively quiescent population of oligodendrocyte precursor cells. J Neurosci. 1998; 18:601-9. https://doi.org/10.1523/JNEUROSCI.18-02-00601.1998.

81. Franklin RJM. Why does remyelination fail in multiple sclerosis? Nat Rev Neurosci. 2002;3:705-14

82. Kuhlmann T, Miron V, Cuo Q, Wegner C, Antel J, Brück W. Differentiation block of oligodendroglial progenitor cells as a cause for remyelination failure in chronic multiple sclerosis. Brain. 2008;131:1749-58.

83. Redwine JM, Armstrong RC. In vivo proliferation of oligodendrocyte progenitors expressing PDGFaR during early remyelination. J Neurobiol. 1998;37:413-28

84. Hinks GL, Franklin RJM. Distinctive patterns of PDGF-A, FGF-2, IGF-I, and TGF- $\beta 1$ gene expression during remyelination of experimentally-induced spinal cord demyelination. Mol Cell Neurosci. 1999;14:153-68.

85. Messersmith DJ, Murtie JC, Le TQ, Frost EE, Armstrong RC. Fibroblast growth factor 2 (FGF2) and FGF receptor expression in an experimental demyelinating disease with extensive remyelination. J Neurosci Res. 2000;62:241-56.

86. Fancy SPJ, Baranzini SE, Zhao C, Yuk D-I, Irvine K-A, Kaing S, et al. Dysregulation of the Wnt pathway inhibits timely myelination and remyelination in the mammalian CNS. Genes Dev. 2009;23:1571-85.

87. Yamaguchi M. Histone deacetylase 1 regulates retinal neurogenesis in zebrafish by suppressing Wnt and Notch signaling pathways. Development. 2005;132:3027-43. https://doi.org/10.1242/dev.01881.

88. Yamamoto A, Nagano T, Takehara S, Hibi M, Aizawa S. Shisa promotes head formation through the inhibition of receptor protein maturation for the caudalizing factors, Wnt and FGF. Cell. 2005;120:223-35.

89. Chen $\mathrm{Y}$, Wang $\mathrm{H}$, Yoon $\mathrm{SO}, \mathrm{Xu} \mathrm{X}$, Hottiger MO, Svaren J, et al. HDACmediated deacetylation of NF-kB is critical for Schwann cell myelination. Nat Neurosci. 2011;14:437-41.

90. Bhat MA, Rios JC, Lu Y, Garcia-Fresco GP, Ching W, Martin MS, et al. Axonglia interactions and the domain organization of myelinated axons requires Neurexin IV/Caspr/Paranodin. Neuron. 2001;30:369-83.

91. Sherman DL, Tait S, Melrose S, Johnson R, Zonta B, Court FA, et al. Neurofascins are required to establish axonal domains for saltatory conduction. Neuron. 2005;48:737-42.

92. Mathey EK, Derfuss T, Storch MK, Williams KR, Hales K, Woolley DR, et al. Neurofascin as a novel target for autoantibody-mediated axonal injury. J Exp Med. 2007;204:2363-72. https://doi.org/10.1084/jem.20071053.

93. Linington C, Engelhardt B, Kapocs G, Lassman $H$. Induction of persistently demyelinated lesions in the rat following the repeated adoptive transfer of encephalitogenic $T$ cells and demyelinating antibody. J Neuroimmunol. 1992;40:219-24.

94. Kaltschmidt B, Kaltschmidt C. NF- kB in the nervous system. Cold Spring Harb Perspect Biol. 2009;1:a001271.

95. Akama KT, Albanese C, Pestell RG, Van Eldik L. Amyloid beta-peptide stimulates nitric oxide production in astrocytes through an NFkappaBdependent mechanism. Proc Natl Acad Sci U S A. 1998;95:5795-800.

96. Castillo-Fernandez JE, Spector TD, Bell JT. Epigenetics of discordant monozygotic twins: Implications for disease. Genome Med. 2014;6:1-16.

97. Healy BC, Ali EN, Guttmann CRG, Chitnis T, Glanz Bl, Buckle G, et al. Smoking and disease progression in multiple sclerosis. Arch Neurol. 2009;66:858-64.

98. Degelman ML, Herman KM. Smoking and multiple sclerosis: a systematic review and meta-analysis using the Bradford Hill criteria for causation. Mult Scler Relat Disord. 2017;17:207-16. 
99. Talhout R, Schulz T, Florek E, van Benthem J, Wester P, Opperhuizen A. Hazardous compounds in tobacco smoke. Int J Environ Res Public Health. 2011;8:613-28

100. Hawkins BT, Abbruscato TJ, Egleton RD, Brown RC, Huber JD, Campos CR, et al. Nicotine increases in vivo blood-brain barrier permeability and alters cerebral microvascular tight junction protein distribution. Brain Res. 2004;1027:48-58.

101. Minagar A, Alexander JS. Blood-brain barrier disruption in multiple sclerosis. Multiple Sclerosis. 2003;9:540-9.

102. Funata N, Song SY, Okeda R, Funata M, Higashino F. A study of experimental cyanide encephalopathy in the acute phase -physiological and neuropathological correlation. Acta Neuropathol. 1984;64:99-107.

103. Wang L, Hagemann TL, Kalwa H, Michel T, Messing A, Feany MB. Nitric oxide mediates glial-induced neurodegeneration in Alexander disease. Nat Commun. 2015;6:8966.

104. Kitamura M, Kasai A. Cigarette smoke as a trigger for the dioxin receptormediated signaling pathway. Cancer Lett. 2007;252:184-94.

105. Quintana FJ. Regulation of central nervous system autoimmunity by the aryl hydrocarbon receptor. Semin Immunopathol. 2013;35:627-35.

106. Quintana FJ, Basso AS, Iglesias AH, Korn T, Farez MF, Bettelli E, et al. Control of Treg and $\mathrm{TH} 17$ cell differentiation by the aryl hydrocarbon receptor. Nature. 2008:453:65-71.

107. Zeilinger S, Kühnel B, Klopp N, Baurecht H, Kleinschmidt A, Gieger C, et al. Tobacco smoking leads to extensive genome-wide changes in DNA methylation. PLoS One. 2013;8:e63812.

108. Neavin DR, Liu D, Ray B, Weinshilboum RM. The Role of the Aryl Hydrocarbon Receptor (AHR) in Immune and Inflammatory Diseases. Int J Mol Sci. 2018;19(12):3851.

109. Duarte JH, Di Meglio P, Hirota K, Ahlfors H, Stockinger B. Differential influences of the aryl hydrocarbon receptor on Th17 mediated responses in vitro and in vivo. PLoS One. 2013:8:e79819.

110. Juricek L, Carcaud J, Pelhaitre A, Riday T, Chevallier A, Lanzini J, et al. AhRdeficiency as a cause of demyelinating disease and inflammation. Sci Rep. 2017;7:9794

111. Rothhammer V, Borucki DM, Garcia Sanchez MI, Mazzola MA, Hemond CC, Regev K, et al. Dynamic regulation of serum aryl hydrocarbon receptor agonists in MS. Neurol Neuroimmunol Neuroinflamm. 2017;4:e359.

112. Kaye J, Piryatinsky V, Birnberg T, Hingaly T, Raymond E, Kashi R, et al. Laquinimod arrests experimental autoimmune encephalomyelitis by activating the aryl hydrocarbon receptor. Proc Natl Acad Sci. 2016;113: e6145-52. https://doi.org/10.1073/pnas.1607843113.

113. Hatton OL, Harris-Arnold A, Schaffert S, Krams SM, Martinez OM. The interplay between Epstein-Barr virus and B lymphocytes: implications for infection, immunity, and disease. Immunol Res. 2014;58:268-76.

114. Ascherio A, Munger KL, Lennette ET, Spiegelman D, Hernán MA, Olek MJ, et al. Epstein-Barr virus antibodies and risk of multiple sclerosis: a prospective study. J Am Med Assoc. 2001;286:3083-8.

115. Olsson T, Barcellos LF, Alfredsson L. Interactions between genetic, lifestyle and environmental risk factors for multiple sclerosis. Nat Rev Neurol. 2017; 13:25-36.

116. Niller HH, Wolf $\mathrm{H}$, Minarovits J. Regulation and dysregulation of Epstein Barr virus latency: implications for the development of autoimmune diseases. Autoimmunity. 2008;41:298-328.

117. Cepok S, Zhou D, Srivastava R, Nessler S, Stei S, Büssow K, et al. Identification of Epstein-Barr virus proteins as putative targets of the immune response in multiple sclerosis. J Clin Invest. 2005;115:1352-60.

118. Robertson KD, Hayward SD, Ling PD, Samid D, Robertson KD, Hayward SD, et al. Transcriptional activation of the Epstein-Barr virus latency $C$ promoter after 5-azacytidine treatment: evidence that demethylation at a single $\mathrm{CpG}$ site is crucial. Mol Cell Biol. 1995;15:6150-9.

119. Engelsen $\mathrm{O}$. The relationship between ultraviolet radiation exposure and vitamin D status. Nutrients. 2010;2:482-495.

120. Holick MF. Sunlight and vitamin D for bone health and prevention of autoimmune diseases, cancers, and cardiovascular disease... Vitamin D and Health in the 21st Century: proceedings of a conference held in Bethesda, MD, October 9-10, 2003. Am J Clin Nutr. 2004;80:1678S

121. Smolders J, Damoiseaux J, Menheere P, Hupperts R. Vitamin D as an immune modulator in multiple sclerosis, a review. J Neuroimmunol. 2008; 194:7-17.

122. Sloka S, Silva C, Pryse-Phillips W, Patten S, Metz L, Yong WW. A quantitative analysis of suspected environmental causes of MS. Can J Neurol Sci. 2011; 38:98-105.
123. Simpson S, Taylor B, Blizzard L, Ponsonby AL, Pittas F, Tremlett H, et al. Higher 25-hydroxyvitamin $\mathrm{D}$ is associated with lower relapse risk in multiple sclerosis. Ann Neurol. 2010;68:193-203.

124. Fetahu IS, Höbaus J, Kállay E. Vitamin D and the epigenome. Front Physiol. 2014;5:1-13.

125. Rawson JB, Sun Z, Dicks E, Daftary D, Parfrey PS, Green RC, et al. Vitamin D intake is negatively associated with promoter methylation of the Wnt antagonist gene DKK1 in a large group of colorectal cancer patients. Nutr Cancer. 2012;64:919-28.

126. Inestrosa NC, Varela-Nallar L. Wht signalling in neuronal differentiation and development. Cell Tissue Res. 2015;359:215-23.

127. Barragán-Martínez C, Speck-Hernández CA, Montoya-Ortiz G, Mantilla RD, Anaya JM, Rojas-Villarraga A, et al. Organic solvents as risk factor for autoimmune diseases: a systematic review and meta-analysis. PLoS One. 2012;7:e51506.

128. Al-Hajri Z, Del Bigio MR. Brain damage in a large cohort of solvent abusers. Acta Neuropathol. 2010;119:435-45.

129. Godderis L, De Raedt K, Tabish AM, Poels K, Maertens N, De Ruyck K, et al. Epigenetic changes in lymphocytes of solvent-exposed individuals. Epigenomics. 2012;4:269-77.

130. Hong JY, Yu SY, Kim SY, Ahn JJ, Kim Y, Kim GW, et al. Association analysis of toluene exposure time with high-throughput mRNA expressions and methylation patterns using in vivo samples. Environ Res. 2016;146:59-64.

131. Wu C, Keightley SY, Leung-Hagesteijn C, Radeva G, Coppolino M, Goicoechea S, et al. Integrin-linked protein kinase regulates fibronectin matrix assembly, E- cadherin expression, and tumorigenicity. J Biol Chem. 1998;273:528-36.

132. Hedström AK, Hössjer O, Katsoulis M, Kockum I, Olsson T, Alfredsson L. Organic solvents and MS susceptibility. Neurology. 2018;91:e455-62. https:// doi.org/10.1212/WNL.0000000000005906.

133. Bagur MJ, Murcia MA, Jiménez-Monreal AM, Tur JA, Bibiloni MM, Alonso GL, et al. Influence of diet in multiple sclerosis: a systematic review. Adv Nutr An Int Rev J. 2017:8:463-47.

134. Wang WW, Lu L, Bao TH, Zhang HM, Yuan J, Miao W, et al. Scutellarin alleviates behavioral deficits in a mouse model of multiple sclerosis, possibly through protecting neural stem cells. J Mol Neurosci. 2016;58:210-20.

135. Hendriks JJA, Alblas J, van der Pol SMA, van Tol EAF, Dijkstra CD, de Vries HE. Flavonoids influence monocytic GTPase activity and are protective in experimental allergic encephalitis. J Exp Med. 2004;200:1667-72. https://doi. org/10.1084/jem.20040819.

136. Sternberg Z, Chadha K, Lieberman A, Hojnacki D, Drake A, Zamboni P, et al. Quercetin and interferon- $\beta$ modulate immune response(s) in peripheral blood mononuclear cells isolated from multiple sclerosis patients. J Neuroimmunol. 2008;205:142-7. https://doi.org/10.1016/j.jneuroim.2008.09. 008 .

137. Ross SA, Poirier L. Proceedings of the Trans-HHS Workshop: diet, DNA methylation processes and health. J Nutr. 2002;132:2329S-2332S

138. Dickson KM, Gustafson CB, Young Jl, Züchner S, Wang G. Ascorbate-induced generation of 5-hydroxymethylcytosine is unaffected by varying levels of iron and 2-oxoglutarate. Biochem Biophys Res Commun. 2013;439:522-7. https://doi.org/10.1016/j.bbrc.2013.09.010.

139. Singhal NK, Freeman E, Arning E, Wasek B, Clements R, Sheppard C, et al. Dysregulation of methionine metabolism in multiple sclerosis. Neurochem Int. 2018;112:1-4. https://doi.org/10.1016/j.neuint.2017.10.011.

140. Strickland FM, Hewagama A, Wu A, Sawalha AH, Delaney C, Hoeltzel MF, et al. Diet influences expression of autoimmune-associated genes and disease severity by epigenetic mechanisms in a transgenic mouse model of lupus. Arthritis Rheum. 2013;65:1872-81.

141. Singhal NK, Li S, Arning E, Alkhayer K, Clements R, Sarcyk Z, et al. Changes in methionine metabolism and histone $\mathrm{H} 3$ trimethylation are linked to mitochondrial defects in multiple sclerosis. J Neurosci. 2015;35:15170-86. https://doi.org/10.1523/JNEUROSCI.4349-14.2015.

142. Zhou X, Zhang L, Ji WJ, Yuan F, Guo ZZ, Pang B, et al. Variation in dietary salt intake induces coordinated dynamics of monocyte subsets and monocyteplatelet aggregates in humans: implications in end organ inflammation. PLoS One. 2013;8;e60332.

143. Hernandez AL, Kleinewietfeld M, David A, Hernandez AL, Kitz A, Wu C, et al. Sodium chloride inhibits the suppressive function of FOXP3 + regulatory $T$ cells. J Clin Invest. 2015;125:4212-22.

144. Hucke S, Eschborn M, Liebmann M, Herold M, Freise $N$, Engbers $A$, et al. Sodium chloride promotes pro-inflammatory macrophage polarization 
thereby aggravating CNS autoimmunity. J Autoimmun. 2016;67:90-101. https://doi.org/10.1016/j.jaut.2015.11.001.

145. Zhang T, Fang S, Wan C, Kong Q, Wang G, Wang S, et al. Excess salt exacerbates blood-brain barrier disruption via a p38/MAPK/SGK1-dependent pathway in permanent cerebral ischemia. Sci Rep. 2015;5. https://doi.org/10. 1038/srep16548.

146. Farez MF, Fiol MP, Gaitán MI, Quintana FJ, Correale J. Sodium intake is associated with increased disease activity in multiple sclerosis. J Neurol Neurosurg Psychiatry. 2015;86:26-31.

147. Mischke M, Plösch T. The gut microbiota and their metabolites: potential implications for the host epigenome. Adv Exp Med Biol. 2016;902:33-44.

148. Berer K, Mues M, Koutrolos M, AlRasbi Z, Boziki M, Johner C, et al. Commensal microbiota and myelin autoantigen cooperate to trigger autoimmune demyelination. Nature. 2011;479:538-41. https://doi.org/10.1038/nature10554.

149. Lee YK, Menezes JS, Umesaki Y, Mazmanian SK. Proinflammatory T-cell responses to gut microbiota promote experimental autoimmune encephalomyelitis. Proc Natl Acad Sci. 2011;108(Supplement_1):4615-22. https://doi.org/10.1073/pnas.1000082107.

150. Chen J, Chia N, Kalari KR, Yao JZ, Novotna M, Soldan MMP, et al. Multiple sclerosis patients have a distinct gut microbiota compared to healthy controls. Sci Rep. 2016;6:1-10. https://doi.org/10.1038/srep28484.

151. Berer K, Gerdes LA, Cekanaviciute E, Jia X, Xiao L, Xia Z, et al. Gut microbiota from multiple sclerosis patients enables spontaneous autoimmune encephalomyelitis in mice. Proc Natl Acad Sci. 2017;114:10719-24.

152. Sun CY, Chang SC, Wu MS. Suppression of Klotho expression by proteinbound uremic toxins is associated with increased DNA methyltransferase expression and DNA hypermethylation. Kidney Int. 2012;81:640-50.

153. Torres PU, Prié D, Molina-Blétry V, Beck L, Silve C, Friedlander G. Klotho: An antiaging protein involved in mineral and vitamin D metabolism. Kidney Int. 2007;71:730-7.

154. Afanas'ev I. New nucleophilic mechanisms of Ros-dependent epigenetic modifications: comparison of aging and cancer. Aging Dis. 2014;5:52-62

155. Anderson OS, Sant KE, Dolinoy DC. Nutrition and epigenetics: an interplay of dietary methyl donors, one-carbon metabolism and DNA methylation. $J$ Nutr Biochem. 2012;23:853-9.

156. Kalhan SC. One-carbon metabolism, fetal growth and long-term consequences. In: Nestle Nutrition Institute Workshop Series; 2013.

157. Ly A, Lee H, Chen J, Sie KKY, Renlund R, Medline A, et al. Effect of maternal and postweaning folic acid supplementation on mammary tumor risk in the offspring. Cancer Res. 2011;71:988-97.

158. Dumas M-E, Barton RH, Toye A, Cloarec O, Blancher C, Rothwell A, et al. Metabolic profiling reveals a contribution of gut microbiota to fatty liver phenotype in insulin-resistant mice. Proc Natl Acad Sci. 2006;103:12511-6.

159. Schaible TD, Harris RA, Dowd SE, Smith CW, Kellermayer R. Maternal methyldonor supplementation induces prolonged murine offspring colitis susceptibility in association with mucosal epigenetic and microbiomic changes. Hum Mol Genet. 2011;20:1687-96.

160. Canani RB, Costanzo MD, Leone L. The epigenetic effects of butyrate: potential therapeutic implications for clinical practice. Clin Epigenetics. 2012; 4:1-7.

161. Kanai Y, Hirohashi S. Alterations of DNA methylation associated with abnormalities of DNA methyltransferases in human cancers during transition from a precancerous to a malignant state. Carcinogenesis. 2007; 28:2434-42.

162. Worthley DL, Whitehall VLJ, Le Leu RK, Irahara N, Buttenshaw RL, Mallitt KA, et al. DNA methylation in the rectal mucosa is associated with crypt proliferation and fecal short-chain fatty acids. Dig Dis Sci. 2011;56:387-96.

163. Hou H, Yu H. Structural insights into histone lysine demethylation. Curr Opin Struct Biol. 2010;20:739-48.

164. Wang L, Chang J, Varghese D, Dellinger M, Kumar S, Best AM, et al. A smal molecule modulates Jumonji histone demethylase activity and selectively inhibits cancer growth. Nat Commun. 2013:4:2035.

165. Minor EA, Court BL, Young Jl, Wang G. Ascorbate induces ten-eleven translocation (Tet) methylcytosine dioxygenase-mediated generation of 5hydroxymethylcytosine. J Biol Chem. 2013;288:13669-74.

166. Kumar H, Lund R, Laiho A, Lundelin K, Ley RE, Isolauri E, et al. Gut microbiota as an epigenetic regulator: pilot study based on whole-genome methylation analysis. MBio. 2014;5:e02113-14.

167. Denham J, O'Brien BJ, Marques FZ, Charchar FJ. Changes in the leukocyte methylome and its effect on cardiovascular-related genes after exercise. J Appl Physiol. 2015;118:475-88. https://doi.org/10.1152/japplphysiol.00878.2014.
168. Radom-Aizik S, Zaldivar F, Leu SY, Adams GR, Oliver S, Cooper DM. Effects of exercise on microRNA expression in young males peripheral blood mononuclear cells. Clin Transl Sci. 2012;5:32-8.

169. Gomez-Pinilla F, Zhuang Y, Feng J, Ying Z, Fan G. Exercise impacts brainderived neurotrophic factor plasticity by engaging mechanisms of epigenetic regulation. Eur J Neurosci. 2011;33:383-90.

170. Briken S, Rosenkranz SC, Keminer O, Patra S, Ketels G, Heesen C, et al. Effects of exercise on Irisin, BDNF and IL-6 serum levels in patients with progressive multiple sclerosis. J Neuroimmunol. 2016;299:53-8. https://doi.org/10.1016/j. jneuroim.2016.08.007.

171. Lewin GR. Physiology of the Neurotrophins. Annu Rev Neurosci. 1996;19: 289-317.

172. Stadelmann C, Kerschensteiner M, Misgeld T, Brück W, Hohlfeld R, Lassmann H. BDNF and gp145trkB in multiple sclerosis brain lesions: neuroprotective interactions between immune and neuronal cells? Brain. 2002:125:75-85.

173. Kerschensteiner M, Gallmeier E, Behrens L, Leal W, Misgeld T, Klinkert WE, et al. Activated human T cells, B cells, and monocytes produce brainderived neurotrophic factor in vitro and in inflammatory brain lesions: a neuroprotective role of inflammation? J Exp Med. 1999:189:865-70.

174. Vaynman S, Ying Z, Gomez-Pinilla F. Hippocampal BDNF mediates the efficacy of exercise on synaptic plasticity and cognition. Eur J Neurosci. 2004;20:2580-90.

175. Xiao J, Wong AW, Willingham MM, Van Den Buuse M, Kilpatrick TJ, Murray SS. Brain-derived neurotrophic factor promotes central nervous system myelination via a direct effect upon oligodendrocytes. NeuroSignals. 2011; 18:186-202.

176. Sølvsten CAE, De Paoli F, Christensen JH, Nielsen AL. Voluntary physical exercise induces expression and epigenetic remodeling of VegfA in the rat hippocampus. Mol Neurobiol. 2016;55:567-82.

177. Lin W. Neuroprotective effects of vascular endothelial growth factor A in the experimental autoimmune encephalomyelitis model of multiple sclerosis. Neural Regen Res. 2017;12:70-1.

178. Keane RW, Dietrich WD, de Rivero Vaccari JP. Inflammasome proteins as biomarkers of multiple sclerosis. Front Neurol. 2018;9:135.

179. Nakajima K, Takeoka M, Mori M, Hashimoto S, Sakurai A, Nose H, et al. Exercise effects on methylation of ASC gene. Int J Sports Med. 2010;31:671-5.

180. Slattery ML, Curtin K, Sweeney C, Levin TR, Potter J, Wolff RK, et al. Diet and lifestyle factor associations with $\mathrm{CpG}$ island methylator phenotype and BRAF mutations in colon cancer. Int J Cancer. 2006;120:656-63.

181. Zhang FF, Cardarelli R, Carroll J, Zhang S, Fulda KG, Gonzalez K, et al. Physical activity and global genomic DNA methylation in a cancer-free population. Epigenetics. 2011;6:293-9.

182. White AJ, Sandler DP, Bolick SCE, Xu Z, Taylor JA, Deroo LA. Recreational and household physical activity at different time points and DNA global methylation. Eur J Cancer. 2013;49:2199-206. http://sci-hub.tw/10.1016/j. ejca.2013.02.013

183. Mohr DC. Association between stressful life events and exacerbation in multiple sclerosis: a meta-analysis. BMJ. 2004;328:731. http://scihub.tw/1 $0.1136 / \mathrm{bmj} .38041 .724421 .55$.

184. Liu XJ, Ye HX, Li WP, Dai R, Chen D, Jin M. Relationship between psychosocial factors and onset of multiple sclerosis. Eur Neurol. 2009;62: 130-6.

185. Babenko O, Kovalchuk I, Metz GAS. Stress-induced perinatal and transgenerational epigenetic programming of brain development and mental health. Neurosci Biobehav Rev. 2015;48:70-91. http://sci-hub.tw/10.1 016/j.neubiorev.2014.11.013.

186. Garabedian MJ, Harris CA, Jeanneteau F. Glucocorticoid receptor action in metabolic and neuronal function. F1000Res. 2017;6:1208. http://scihub.tw/1 0.12688/f1000research.11375.1.

187. Matysiak M, Makosa B, Walczak A, Selmaj K. Patients with multiple sclerosis resisted to glucocorticoid therapy: abnormal expression of heat-shock protein 90 in glucocorticoid receptor complex. Mult Scler. 2008;14:919-26.

188. Constantinescu CS, Faroogi N, O'Brien K, Gran B. Experimental autoimmune encephalomyelitis (EAE) as a model for multiple sclerosis (MS). Br J Pharmacol. 2011;164:1079-106

189. Barthelmes J, Tafferner N, Kurz J, de Bruin N, Parnham MJ, Geisslinger G, et al. Induction of experimental autoimmune encephalomyelitis in mice and evaluation of the disease-dependent distribution of immune cells in various tissues. J Vis Exp. 2016:1-10. http://dx.doi.org/10.3791/53933.

190. Schmitz K de Bruin N, Bishay P, Mannich J, Haussler A, Altmann C, et al. Rflurbiprofen attenuates experimental autoimmune encephalomyelitis in 
mice. EMBO Mol Med. 2014;6:1398-422. http://dx.doi.org/10.15252/emmm.2 01404168.

191. Catanzaro G, Pucci M, Viscomi MT, Lanuti M, Feole M, Angeletti S, et al. Epigenetic modifications of Dexras 1 along the nNOS pathway in an animal model of multiple sclerosis. J Neuroimmunol. 2016;294:32-40. http://dx.doi. org/10.1016/j.jneuroim.2016.03.009.

192. Noori-Zadeh A, Mesbah-Namin SA, Saboor-Yaraghi AA. Epigenetic and gene expression alterations of FOXP3 in the T cells of EAE mouse model of multiple sclerosis. J Neurol Sci. 2017;375:203-8.

193. Fontenot JD, Gavin MA, Rudensky AY. Foxp3 programs the development and function of CD4+CD25+ regulatory T cells. J Immunol. 2017;198:986-92.

194. Blakemore WF, Franklin RJM. Remyelination in experimental models of toxin-induced demyelination. Curr Top Microbiol Immunol. 2008;318:193212.

195. Matsushima GK, Morell P. The neurotoxicant, cuprizone, as a model to study demyelination and remyelination in the central nervous system. Brain Pathol. 2001;11:107-16.

196. Moyon S, Ma D, Huynh JL, Coutts DJC, Zhao C, Casaccia P, et al. Efficient remyelination requires DNA methylation. eneuro. 2017:4:ENEURO.0336-16. 2017.

197. Minor EA, Court BL, Young JI, Wang G. Ascorbate induces ten-eleven translocation (Tet) methylcytosine dioxygenase-mediated generation of 5-hydroxymethylcytosine. J Biol Chem. 2013;288:13669-74.

\section{Publisher's Note}

Springer Nature remains neutral with regard to jurisdictional claims in published maps and institutional affiliations.

Ready to submit your research? Choose BMC and benefit from:

- fast, convenient online submission

- thorough peer review by experienced researchers in your field

- rapid publication on acceptance

- support for research data, including large and complex data types

- gold Open Access which fosters wider collaboration and increased citations

- maximum visibility for your research: over $100 \mathrm{M}$ website views per year

At BMC, research is always in progress.

Learn more biomedcentral.com/submissions 